\title{
LA PREILUSTRACIÓN EN LOS MEDIOS ECLESIÁSTICOS DE MALLORCA (SS. XVII-XVIII)*
}

por

\author{
JOSEP AMENGUAL I BATLE \\ M.SS.CC.
}

RESUMEN: 'Ante ciertos datos, cada vez más numerosos, referentes a personas de talante filoliberal en la sociedad y, sobre todo, entre los eclesiásticos de Mallorca pertenecientes al s. $X I X$, el artículo parte de la sospecha de que esta corriente no despertó espontáneamente. Por ello discute que una bistoriografia marcadamente restauracionista nos bubiera legado una imagen suficientemente matizada del colectivo eclesiástico mallorquín. Apunta ciertas vinculaciones del mismo con algunos protagonistas de la Ilustración. Se estudian antecedentes de la renovación científica en la Universidad de Mallorca y en el lulismo. Merece la atención del paso de las tertulias de salón a la Sociedad Económica Mallorquina de los Amigos del País. Entre los protagonistas se mencionan a Bonaventura Serra, Antoni Roig i Rexach, Bernat Nadal Crespí, Lluís de Vilafranca y Cristòfor Cladera Company; todos ellos sólo inicialmente considerados por los historiadores.

Palabras Clave: Mallorca. Iglesia. Preilustración. Historiografia. Liberalismo. Reacción. Universidad. Lulismo.

ABSTRACT: In face of certain increasingly numerous data relating to people of filoliberal bearing in the society and, above all, among the clergymen of Mallorca of the XIX century, the article parts from the suspicion that this current did not awaken spontaneously. Because of this it questions that a notably restorationalist bistoriography would have bequeathed us a sufficiently accurate image of the Majorcan ecclesiastical

* Para la identificación de las personas, de las cabeceras de prensa, etc., son muy útiles la Gran Enciclopèdia de Mallorca, 1-19, (Mallorca) 1989-1998 y la Gran Enciclopèdia Catalana, (Barcelona) en sus dos ediciones. La sigla BSAL (Mallorca) identifica el Boletín de la Sociedad Arqueológica Luliana (1885-1978) o en su actual cabecera en catalán, Bolletí de la Societat Arqueològica Lul-liana. Abreviamos la referencia al repertorio de Joaquim Ma . BOVER DE ROSSELLÓ: Biblioteca de Escritores Baleares, I-II, Palma, 1868 (reproducción Barcelona-Sueca 1975) escribiendo su apellido, seguido de la indicación del tomo, número y página que interesa. Generalmente abreviaremos la referencia a la Sociedad Económica Mallorquina de Amigos del País, con sus iniciales: SEMAP.

Hispania, LXII/3, núm. 212 (2002) 907-956 
collectivity. It aims toward certain ties of these with some protagonists of the Illustration. Attention is deserved to the passing from the salon gatherings to "Sociedad Económica Mallorquina de los Amigos del País". Among the protagonists mentioned are Bonaventura Serra, Antoni Roig $i$ Rexach, Bernat Nadal Crespi, Lluís de Vilafranca and Cristofor Cladera Company; all of them only initially considerated by historians.

KEY WORDS: Mallorca. Church. Preilustration. Historiography. Liberalism. Reaction. University. Lullism.

\section{HISTORIOGRAFÍAS CONTRAPUESTAS}

Ha sido un lugar común considerar a la isla de Mallorca como un reducto de pensamiento reaccionario. A ello contribuyó notablemente un hecho indiscutible, la avalancha de refugiados llegados a causa de la guerra del francés (1808-1814). Se consolidaron las posturas tradicionalistas y se les añadieron nuevas y cualificadas fuerzas, aportadas a la Isla en un momento crucial, justo cuando antiguos ilustrados llevaban años de vuelta sobre sus pasos, aterrorizados por los resultados de la revolución francesa, y cuando el patriotismo alcanzó grados inigualados de entusiasmo con la invasión de Napoleón. Miedo a la libertad y defensa del extranjero frenaron una lenta, pero progresiva, evolución. No en vano el liberal mallorquín más significativo de la primera hora, Guillem Ignasi de Montis (1774-1829), el 4 de junio de 1804 escribía con enorme clarividencia y con intuición sobre cuál sería su destino:

«[...] los mismos franceses que guillotinaron a Luis XVI han proclamado emperador a Napoleón Bonaparte, y su revolución será un ejemplo fatal a cuantos la intenten y al mismo tiempo un nuevo motivo para que los reyes afirmen su despotismo»1.

\footnotetext{
1 Carta 21, 4 de junio ¿1804?, en MOLL BlanES, Isabel: «El liberalisme a la Il-lustració mallorquina. En Guillem Ignasi de Montis", en Randa, Història i literatura a Mallorca i Eivissa, (Barcelona) (Curial) 7 (1978) pp. 167-209. El texto se halla en la p. 201. Cf. carta 23, p. 205, donde copia unos versos de DE LA FONTAINE, seguidos de un escueto comentario: «Fable de la Fontaine

Un bloc de marbre était si beau

qu'un statuaire en fit l'emplette qu'en fera dit-il mon cizeu? sera-t-il, dieu, table ou cuvette? Il sera dieu; meme je veux qu'il ait en sa main un tonnerre tremblez humains; faites des veux voilá le maitre de la terre. Etc.

Yo no sé si hallarás a qué aplicarla. Pero a mí me parece que si has leído los papeles públicos de los franceses y el modo como éstos han variado de sistema y la fuerza que han depositado en Bonaparte, fácilmente aplicarás el cuento».
}

Hispania, LXII/3, núm. 212 (2002) 907-956 
De Montis, hijo de un contertulio de Bonaventura Serra, luego fue uno de los fundadores de la Sociedad Económica Mallorquina de Amigos del País. De Montis llegaría a ocupar el cargo de secretario de la misma (1804-1808). Entró en la carrera militar, heredó el título de marqués de la Bastida y, por haber ejercido como Jefe Político en la primera etapa liberal (1813-1814) conoció la cárcel y el destierro, antes de repetir en el cargo (1821-1822).

Con todo, volvamos a la mencionada línea historiográfica, prevalentemente mallorquina, que denuncia como extraños los brotes de apertura a las nuevas corrientes de pensamiento. Por el camino de lo que sería una tradición ininterrumpida hasta los comienzos del s. XIX, se procede a excluir de la tradición a los que, durante el s. XVIII, promovieron un cierto aperturismo que puede ser considerado como el antecedente de los inicios del liberalismo en Mallorca. Por esto, no sólo hemos de tener presente que se dio una tensión entre Mallorca y las nuevas ideas importadas, sino que interesa que nos percatemos de la incomodidad de bastantes historiadores, al comprobar que el mundo ideológico de los estudiosos, que hemos mencionado en primer término, se confundía con lo que se ha llamado el antiguo régimen.

\section{Dualismo Palma - Cádiz}

A menudo se ha considerado a Mallorca como el foco opuesto a la tendencia liberalizante de Cádiz con sus Cortes. No hay especial dificultad para aceptar que la balanza se inclinó en sentido opuesto en estos dos lugares. Las ideas de los políticos congregados y triunfantes eran liberales en Cádiz, y las de los obispos y frailes refugiados en Mallorca eran reaccionarias. Estos grupos no quedaron cerrados en sí mismos. Los ánimos en uno y otro lugar se caldeaban con mensajes de tendencia bien opuesta y se difundía una forma diversa de ver la vida. Ambas ciudades conocieron una profusión de prensa periódica, que ya entonces llamó la atención ${ }^{2}$. Los sermones incendiarios se prodigaron en Mallorca, en contra de la voluntad del obispo, enviado a Cádiz como diputado de $\mathrm{Palma}^{3} \mathrm{y}$, al margen de él, los obispos refugiados en Mallorca reimprimieron su

2 Véase cómo justifica su presencia el primer y único número del periódico servil, editado por Josep Canet, el 21 de junio de 1813, en Nuevo Diario del Liberal Napoleón, «En Cádiz y Palma salen muchos periódicos, bien que de malo a peor...», reproducido por ROURA I AULINAS, Lluís: L'Antic Règim a Mallorca. Abast de la commoció dels anys 1808-1814, Mallorca, 1985, p. 370. Han publicado unas síntesis sobre nuestro tema, RENOM I FERRER, Maria Teresa: Miquel Ferrer i Bauçà, protagonista en la societat de Mallorca. Abadia de Montserrat, Biblioteca Abat Oliba, 196, 1998, Capítol II, pp. 33-104 y Pere Fullana PuigServer, "L'església de Mallorca a la vigília de la guerra del francès", en $B S A L$ (Mallorca) 55 (1999) 239-248.

3 RoURA I AULINAS, L'Antic Règim a Mallorca, pp. 412-414, ofrece un listado de publicaciones en torno a esta cuestión. Véase, también, DURAN PASTOR, Miquel: Bernat Nadal $i$ Crespí. Un bisbe solleric que fou diputat a les Corts de Cadis, Palma, Biografies de mallorquins, 13, 1986, pp. 105-108, con un listado de publicaciones, paralelo al que trae Roura i Aulinas. 
Instrucción pastoral de los Ilustrísimos obispos de Lérida, Tortosa, Barcelona, Urgel, Teruel y Pamplona. Al clero y pueblo de sus diócesis, denunciando toda innovación y, sobre todo, defendiendo las inmunidades eclesiásticas ${ }^{4}$.

Esta visión dualista ha originado la mencionada historiografía, con trazos casi deterministas, de modo que cerrazón a las nuevas ideas y conservadurismo político y eclesiástico se consideraron como signos de autenticidad mallorquina. En otro sentido Palma habría sido un foco compacto antiliberal, frente a Cádiz. $\mathrm{Ha}$ dado pie a este enfoque la obra del que fue director del periódico «La Vanguardia» de Barcelona, Miquel dels Sants Oliver, Mallorca durante la primera revolución ${ }^{5}$. De su minuciosa búsqueda en los archivos de la prensa contemporánea de los hechos dependen la mayoría de los historiadores posteriores. Cuestión muy diversa es que los que aprovechan su labor y le citan tengan una misma línea de interpretación.

\section{En Mallorca, un dualismo interno}

Los materiales ensamblados por Oliver han originado otra corriente historiográfica que ha resaltado sobre todo la dualidad en Mallorca misma, de manera que han querido reflejar la conflictividad ideológica que allí existió. Por un lado, se ha lamentado la tarea propagandística de Isidoro Antillón, magistrado de la Audiencia, de Miguel Victorica, clérigo, fiscal de la Inquisición, ambos llegados de la Península, y la del joven aristócrata mallorquín Guillem Ignasi de Montis ${ }^{6}$, que se les unió entusiásticamente. Los tres fundaron en junio de

${ }^{4}$ Reimpresa en Mallorca. Año de 1814. Los editores en su presentación - sin paginar - la llaman «Encíclica pastoral [...] para preservativo del contagio de errores». Cf. REvUELTA GONZÁLEZ, Manuel: La Iglesia española ante la crisis del antiguo régimen (1898-1833), en GARCíA-VILlosLADA, Ricardo (Director) Historia de la Iglesia en la España contemporánea, V, Madrid, BAC maior 20, 1979, pp. 63-64, donde describe los rasgos extremosos de este escrito.

s OLIVER, Miquel dels Sants: Mallorca durante la primera revolución (1808 á 1814) Palma Imprenta de Amengual y Muntaner, 1901, IX +686 págs. [Hay una reimpresión anàstatica en 3 tomos, Palma, Luis Ripoll, Editor, 1982 y otra más reciente, Obres Completes, 1-2: Transcripció i correcció, Aguiló, Agustí Josep. Estudi preliminar, Fullana i Puigserver, Pere. I-II, Mallorca, Lleonard Muntaner Editor, 1999, 283 y 276 pàgs.].

6 Sin que las ideas de de Montis sean estrictamente piadosas, en la correspondencia que conocemos, anterior a la guerra del francés, se manifiesta crítico con ciertas frivolidades del obispo Nadal y de otros eclesiásticos, pero respetuoso con la Iglesia, al tiempo que muestra su desacuerdo con las actitudes libertinas de la aristocracia, cf. MOLL BLANES: «El liberalisme a la Il-lustració mallorquina», pp. 167-209. Véanse por ejemplo, las cartas 7, p.182-183; carta 8, p. 183, donde dice del obispo: Bernardus passatus ad omnia; carta 9, p. 185, sobre el obispo y la aristocracia; p. 187, sobre escándalos de la aristocracia; la misma crítica en la carta 10, p. 187; carta 14, del 30 de septiembre de 1804 [tocar decir ¿1803?] se alegra de que se mitigue la prisión de Jovellanos; en la carta 17, del 7 de enero de 1804, p. 196, escribe: "Los nobles de la Vila callan como unos muertos, pues no pueden conciliar una muerte cristiana con las vanas ideas de sostener la enemistad hasta la última hora». El autor de la denuncia anónima, datada el 18 de julio de 1809, contra el obispo Nadal, 
1812 el periódico Aurora Patriótica Mallorquina ${ }^{7}$. Añadamos que ha quedado en la penumbra la colaboración, ya desde los inicios de la Aurora, del antiguo capuchino catalán, refugiado en Mallorca, Josep Badia (1777-1850) capellán del regimiento de suizos, de Wimpffen, cargo que había ocupado el franciscano Raimon Strauch i Vidal ${ }^{8}$, antes de que fuera nombrado obispo de Vic. La Inquisición prohibió su opúsculo picante, Un bosquejo de los fraudes, que las pasiones de los bombres introdujeron en nuestra religion ${ }^{9}$. Murió siendo párroco en Francia ${ }^{10}$.

Por su parte, el P. Strauch, traductor de las Memorias para servir a la Historia del Jacobinismo del abate Barruel, se colocó en el extremo opuesto de la Aurora, con el Semanario Cristiano-Político de Mallorca, que llegó a conformar la opinión pública conservadora, y en el cual las citas de Augustin Barruel (17411820) son frecuentes ${ }^{11}$. Este jesuita francés, con una biografía muy zarandeada

Josep Sanglada de Togores, Victorica, de Montis, etc., se corresponde con las frases transcritas de de Montis, cuando se le acusa de ser «un discípulo de Volter consumado, sin mas religión que la superficial, para hacer ver que es cristiano, cuio nombre no merece», en Roura i AulinAs: L'Antic Règim a Mallorca, p. 288. De Montis, en las cartas 22, p. 202 y 23, pp. 204-205, muestra su amistad con un Padre Company.

7 MUNAR, Gaspar: Breve biografía del M. Rdo. D. Gabriel Mariano Ribas de Pina, Mallorca 1973, pp. $15-16$

8 Strauch nació en Tarragona el año 1760, hijo de un capitán del regimiento de suizos. Contaba pocos meses, cuando la familia pasó a residir en Mallorca. Ejerció su docencia como catedrático de filosofía y teología en la Universidad Literaria de Mallorca, durante 13 años. Fue uno de los redactores de la Instrucción pastoral, que hemos mencionado. Hay que decir que el hecho de haber dejado sus diócesis disminuyó el prestigio de la protesta y de las mismas personas. El año 1817 fue nombrado obispo de Vic. Encarcelado en 1820, murió víctima de un atentado cuando era conducido a Barcelona.

9 Véase CoRominas, Joan: Suplemento al Diccionario Crítico de los Escritores Catalanes (Burgos, 1849) [de Torres Amat, Fèlix] Barcelona-Sueca, Curial. Documents de cultura-facsímils 1973, s. v. «Badia; (D. José) pp. 22-23 y «Badia, Josep», en Gran Enciclopedia de Mallorca, (Mallorca) 1 (1989) 291.

10 MenÉndez Pelayo, Marcelino: Historia de los Heterodoxos Españoles, II: Protestantismo y sectas místicas. Regalismo y Enciclopedia. Heterodoxia en el siglo XIX, Madrid ${ }^{2} 1967$, BAC 151, p. 734, donde se le considera como principal redactor; Roura i AULINAS: L'Antic Règim a Mallorca, p. 284, nota 105; FERRER, Antoni-Lluc: «Aspectes de la difusió de la premsa política durant la Guerra del Francès (1808-1814). Els casos de l'»Aurora Patriótica Mallorquina» i del «Semanario Cristiano Político de Mallorca», Randa, 7: Història i literatura a Mallorca i Eivissa, Barcelona, Curial, 1978, p. 43.

11 Siguiendo muy de cerca a OLIVER: Mallorca durante las primera revolución, HeRRERO, Javier: Los orígenes del pensamiento reaccionario español, Madrid, Edicusa, 1973, pp. 343-372, estudia el caso de Mallorca. Sobre todo en las pp. 27-53 y 151-218, aporta numerosos datos sobre el carácter «extranjerizante» del pensamiento reaccionario que asumieron los obispos y frailes españoles de comienzo del s. XIX. Por lo que la tradición supuestamente española no empalmaría con los teólogos de los ss. XVI-XVII. Herrero pretende demostrar que Menéndez Pelayo y su reciente escuela, grandes defensores de la tradición española, no tienen el menor contacto con la España del XVI-XVII, o. c., p. 24. En este momento me abstengo de muchos detalles; baste decir que la tesis de la "tradición española» margina a Bartolomé de Las Casas, y que la teoría de Francisco de Victoria de que es la 
por los cambios políticos, por la supresión y restauración de la Compañía de Jesús, es autor de numerosos escritos publicísticos y apologéticos. Algunos de ellos fueron traducidos por Strauch y, entre sus muchas ediciones, algunas se publicaron en Mallorca ${ }^{12}$. Con el fraile franciscano, además de la nutrida clientela mallorquina, estaba la masa de eclesiásticos fugitivos de sus sedes episcopales, abaciales o simplemente conventuales. De todos estos grupos conocemos suscriptores a la obra de Barruel, Historia del Jacobinismo. Sus nombres figuran en los listados de suscriptores ${ }^{13}$. Por supuesto, los refugiados en general no tenían motivos particulares para simpatizar con las nuevas ideas, siendo así que su huida se debía a la invasión de Napoleón, considerado como el heredero de la Revolución. Y, no lo olvidemos, si la ciudad de Palma entonces rondaba los 33.000 habitantes, el total de refugiados, que soportaron sus entonces menguadas estructuras urbanas y hospitalarias, oscilaba entre los las 15.000 o 17.000 personas, en 1812, cantidad mucho menor que las que a veces se han apuntado, que hacían subir hasta los 30.000 desplazados desde la Península ${ }^{14}$, cifra con la cual se hubiera duplicado la población ordinaria de la ciudad.

La animación de la prensa periódica y las frenéticas reimpresiones de obras publicadas en Cádiz y otros lugares, añadidas a la afluencia de foráneos, dio argumentos a Mn. Josep Barberí, quien a mediados de 1811 escribía que «La isla ahora abunda de muchísima gente extrangera y parece una pequeña corte o una nueva Cádiz» ${ }^{15}$.

Ésta es una observación más, que conduce a inventariar el hecho de que en Mallorca había un consumo de los productos que difundían las nuevas ideas.

sociedad la que debe gobernarse a sí misma y que a ella compete administrarse y dirigir hacia el bien común todos sus poderes, "pareció peligrosa a los neoescolásticos", según observa ANDRÉs, Melquíades: Historia de la Teología Española en el s. XVI, II, Madrid, BAC maior 14, 1977, pp. 480-482. La neoescolástica imperante e impuesta en la formación clerical colocó entre los adversarios de sus tesis de ética a los autores hispánicos aquí señalados; lo obsoleto de tales tesis es patente. Es posible que la mayoría de Cádiz pecara de ingenua, o de anacronismo al apelar a la tradición. La ruptura entre los escolásticos españoles y la vida política del país fue tan llamativa, que, por ejemplo, Enrique Tierno Galván, Manuel Tuñón de Lara, etc., han podido decir que la mayoría de Cádiz tuvo necesidad de «inventar una tradición española», cf. TUÑón DE LARA, M.: La España del siglo XIX, Barcelona 1974, p. 26.

${ }_{12}$ Memorias para servir á la bistoria del jacobinismo escritas en francés por el abate Barruel; traducidas al castellano por F(ray\}. R \{amón\}. S\{trauch\}. V(idal). Observante de la provincia de Mallorca. I-IV, En la Imprenta de Felipe Guasp, Palma 1813; aunque no aparezca el nombre del traductor, por las características de la edición, parece que fue también Strauch quien cuidó de que saliera a luz en Mallorca la Historia del clero en tiempos de la revolución francesa. Escrita en francés por el abate Barruel, traducida al castellano. Nueva edicion con notas y documentos. En la Imprenta de Felipe Guasp, Palma 1814.

13 Véase el primer tomo, pp. 1-6.

14 ROURA I AULINAS: L'Antic Règim a Mallorca, pp. 141-142. El autor analiza minuciosamente los libros parroquiales, los registros portuarios, etc., tanto en las páginas siguientes a las citadas, como en los detallados apéndices. Su revisión es muy fundada.

is OLIVER: Mallorca durante las primera revolución, p. 356.

Hispania, LXII/3, núm. 212 (2002) 907-956 


\section{CONSERVADURISMO Y EVOLUCIÓN}

Teniendo presentes las acotaciones anteriores, en este ensayo intentaremos ver si las formas de pensar y de investigar se mantuvieron estancadas. También nos interesará saber hasta qué punto elementos que el liberalismo dedujo de la ilustración, tales como los derechos de la persona y la moderna configuración de la sociedad penetraron en Mallorca. Nos centraremos en el período más escasamente estudiado de la historia mallorquina, como es el que abarca los ss. XVII y XVIII. Entramos con ello en el tiempo durante el cual en términos generales nació la llamada Preilustración. ${ }^{16}$ Evidentemente, los inicios del liberalismo, al menos en nuestro caso, habrá que buscarlos en las personas que entraron en el s. XIX.

Hacemos esta prueba, porque consideramos que los acontecimientos de principios del s. XIX no encierran la explicación suficiente de los cambios que tuvieron lugar a lo largo de la centuria. Las nuevas ideas del obispo Bernat Nadal i Crespí (1745-1818) de su vicario general Joan Muntaner i Garcia (1766-1847 $)^{17}$, entre otros eclesiásticos, que no figuran entre los suscriptores de la traducción de Strauch ${ }^{18}$, de Guillem Ignasi Montis, de Ramon Despuig i Safortesa, conde de Montenegro y capitán general, etc., no surgieron por generación espontánea. Cualquiera que sea la postura previa que tengamos, se hace necesario activar nuestra sospecha acerca del origen de este espíritu renovador, que se observa en eclesiásticos, civiles y militares de la isla.

Hay otro cauce por el cual hemos de discurrir. Como muy sintomáticamente lo escribió Gaspar Munar i Oliver, Montis se dejó fascinar por la libertad y el progreso $^{19}$. Entonces es de rigor preguntarse: siendo así que en Mallorca hubo sectores que estuvieron en contacto con preilustrados de la Península y hasta algunos intelectuales mantuvieron correspondencia con exponentes del enciclopedismo francés, ¿es posible que estos intercambios dejaran incontaminados a los eclesiásticos mallorquines? La fuerza innata de la libertad siempre hace conquistas. Y Mallorca no pudo ser una excepción. Por esto, a nuestro parecer, se traicionan los historiadores que detectan la presencia de ráfagas de libertad en Mallorca y, a renglón seguido, descartan que tuviera simpatizantes y adeptos prácticos.

16 BAtLlori, Miquel: «Un problema central del segle XVIII: Il-lustració i cristianisme», reproducido en Id.: A través de la bistòria i la cultura, Abadia de Montserrat, Biblioteca Abat Oliba, 10, 1979, p. 298. Este artículo y otros del mismo autor, en La Il-lustració. Obra completa, vol. IX. Edició a cura de Duran, Eulàlia (dir.) i Solervicens, Josep, (coord.). Pròleg de Mestre, Antoni. València Biblioteca d'estudis i investigacions 3 i 4, 1997.

${ }_{17}$ No trataremos en particular de él, porque su actividad pública cae mas bien dentro del s. XIX.

18 Véase Memorias, I, p. 1, donde figuran los nombres de los obispos de Menorca, Tortosa, Eivissa, Teruel y Cartagena.

19 Munar, Breve biografía, p. 15. 
Para llegar a unos resultados suficientemente sólidos, comenzaremos por hacer una aproximación a las instituciones científicas de la época. No podemos omitir una alusión al lulismo, corriente de pensamiento que animó la vida intelectual de Mallorca, hasta que la universidad fue suprimida.

En un segundo momento, y ya en una cronología avanzada en el s. XVIII, vamos a observar lo que sucede en algunos de los salones de Palma y, como es de obligado acercamiento, entraremos en algunos de los ambientes de la SEMAP.

\section{La Universidad Literaria ${ }^{20}$}

Aunque las crisis económicas y sociales tuvieron un efecto muy retardado en la cultura académica, hemos de decir que, como sucedía en toda la monarquía hispánica, el s. XVII en Mallorca señala un vacío de grandes intelectuales. Por una parte, es obligado recordar que los obispos y los sínodos tenían bajo su responsabilidad y control al Estudio General, en el cual desde su fundación, el año $1483^{21}$, podían estudiar teología los candidatos al ministerio y tantos otros profesionales. El 24 de agosto de 1663 obtuvo de la corte la facultad de otorgar grados académicos, en la misma medida que lo hacía la universidad de Lleida $^{22}$. Por otro lado, este Estudio pasó a ser universidad pontificia el año 1673 , con lo cual los grados conferidos alcanzaron la validez en todo el mundo católico latino. El rey dio la correspondiente aprobación en $1697^{23}$. El gran canciller era el obispo, pero los jurados nombraban el rector, cargo que solía recaer en un canónigo.

La Orden de Predicadores y la de los Frailes Menores de San Francisco, desde la Edad Media tenían sus estudios de filosofía y teología, en los cuales, además de los propios profesos, se matriculaban otros estudiantes externos. Durante la segunda mitad del s. XVI, la recién fundada Compañía de Jesús creó el propio colegio, al lado del templo de Monti-sion. Es una constante en las visitas ad limina que los obispos lo mencionen como un centro de enseñanza de gramática y de artes. Entre los profesores de este colegio destacó el jesuita valenciano, P. Josep de Saragossa i Vilanova (1627-1679) autor de una valiosa producción científica, especialmente en el campo de las matemáticas. Editó alguna de sus obras en Mallorca ${ }^{24}$. A finales del s. XVIII, el convento de los

\footnotetext{
${ }^{20}$ Hemos ofrecido una breve síntesis en Història de l'Església a Mallorca. II, Del Barroc a la Il.lustració (1563-1800). Palma, Refaubetx/12, 2002, pp. 147-158.

${ }^{21}$ Lladó FerRagut, Jaime: Historia del Estudio General Luliano y la Real y Pontificia Universidad Literaria de Mallorca, Palma de Mallorca, 1973, pp. 35 y 40.

22 Miralles SberT, José: «Sobre concesión a la Universidad de Mallorca de la facultad de conferir grados (1670)» en $B S A L$, (Mallorca) 8 (1899-1900) 206-207.

23 LLADÓ FerRAGUT: Historia del Estudio General Luliano, pp. 58-59.

${ }^{24}$ Trigonometria Española, resolución de los triángulos planos, y esféricos, Fabrica, y uso de los Senos y Logarithmos. En Mallorca. Por Francisco Oliver. Año 1672, cf. Bover: II, ap. nº. 713, p. 695 y

Hispania, LXII/3, núm. 212 (2002) 907-956
} 
capuchinos era un centro de preilustración moderada, con un gabinete de antigüedades, otro de historia natural y una rica biblioteca ${ }^{25}$. Uno de sus frailes más relevantes, desde el punto de vista de la apertura a las nuevas corrientes ideológicas, fue fray Miquel de Petra (Miquel Ribot i Serra) (1741-1803) catedrático de filosofía experimental y seguidor de Ramon Llull ${ }^{26}$. También fue docente de teología y matemáticas en la universidad, con una clara predilección por la experimentación. Además, le conocemos como autor de bastantes proyectos arquitectónicos ${ }^{27}$ y miembro de la SEMAP ${ }^{28}$. A él pertenece el que posiblemente sea el único tratado de matemáticas en catalán, compuesto en el s. XVIII ${ }^{29}$.

Si aquí mencionamos la universidad y los estudios de las órdenes religiosas, es porque consideramos que las personas que representaron una cierta apertura hacia los nuevos métodos no florecieron por generación espontánea, ni carecieron de un humus académico. Esta observación es necesaria, si tenemos presente que, hasta nuestros días, durante siglo y medio Mallorca estuvo privada de universidad y hasta no faltaron círculos poco entusiastas por su restauración, alguno de ellos perteneciente a los recientes cultivadores de la historia.

Añadamos a todo un motivo ocasional. Si Roura i Aulinas está de acuerdo con la existencia de un núcleo preilustrado en Mallorca ${ }^{30}$, no obstante, a nuestro parecer hace depender en exceso este círculo de la SEMAP. Como se verá, antes e independientemente de esta entidad, y en especial por la vía del lulismo, la universidad y un sector de los seguidores de esta corriente trabajaron seriamente en la renovación de su método, lo cual implicó una critica textual y un afán de poder confrontarse en plan de igualdad con el pensamiento contemporáneo.

Empecemos por observar la trayectoria de los cultivadores de la filosofía universitaria. Hasta finales del s. XVII, como nos dice Sebastià Trias Mercant,

STIFFONI, Giovanni: Intelectuales, Sociedad y Estado", Madrid 1985, en Historia de España, fundada por Ramón Menéndez Pidal, vol. 29**: La época de los primeros borbones. II. La cultura española entre el Barroco y la Ilustración (circa 1680-1759) pp. 15-17 y 24.

${ }_{25}$ Truas Mercant, Sebastià: Historia del pensament a Mallorca. (I) Dels orígens al segle XIX, Mallorca, Els Treballs y els Dies, 28, 1985, p. 264; DE MONTANER ALONSO, Pedro: «El desaparecido gabinete de Antigüedades de los Capuchinos de Mallorca y el origen de la Colección Vivot», en Mayurqa (Mallorca), $\mathrm{n}^{\circ} .15$ (1976) 199-208.

26 BOVER: II, $\mathrm{n}^{\circ} .919$, p. 100.

27 Bover: II, $\mathrm{n}^{\circ} .919$, pp. 99-100; CANTARELlAS, Catalina: La arquitectura mallorquina desde la Ilustración a la Restauración, Palma de Mallorca, Institut d'Estudis Baleàrics, 1981, p. 151; LÓPEZ BONET, Miquel, Fra Miquel de Petra i la bistòria dels Caputxins a Mallorca, Ajuntament de Palma, 1992; FonT OBRADOR, Bartolomé: Historia de Llucmajor. V: El siglo XVIII, Mallorca, 1986, pp. $657-576$.

28 BOVER: Ibid.

29 SERRA DE MANRESA, Valentí: Els caputxins de Catalunya, de l'adveniment borbònic a la invasió napoleònica: vida quotidiana $i$ institucional, actituds, mentalitat, cultura (1700-1814) Barcelona Col-lectània Sant Pacià, 57.- Facultat de Teologia de Catalunya - Editorial Herder, 1996, p. 179.

30 Roura i AUlinas: L'Antic Règim a Mallorca, pp. 48-53,255. 
se caracterizó por un conservadurismo escolástico, de orientación tomista, junto al cual había las escuelas lulista, escotista y la suarista. Esta impermeabilización se consolidó con las decisiones reales, en concreto las de Carlos II, dominado por sus confesores ${ }^{31}$ La subordinación a de la filosofía a la teología era evidente y la limitación de la libertad ideológica era obra de los dos poderes: del eclesiástico y del real. Pero llega un momento en el cual la protección ante el influjo exterior se atenúa, lo cual tiene consecuencias diversas. Los representantes del tomismo más cerrado se atrincheran para protegerse de nuevas ideas. Otros colegas mallorquines adoptan una actitud ecléctica, paralela a la que tuvo muchos representantes a lo largo y ancho de la Península Ibérica ${ }^{32}$; son principalmente los lulistas ${ }^{33}$, que defienden a su maestro de los ataques de Descartes, Bacon, etc. Sobre su significación singular, en relación con la preilustración, hablaremos más adelante. Una tercera corriente, que tuvo su mejor momento entre los años 1750 y 1790 , no se amedrentó para incluir nuevos temas en su reflexión, como pueden ser el origen de las ideas, el ocasionalismo de Malebranche, la armonía de Leibnitz, una teodicea que es basa en Dios como espíritu, etc., y, acercándose a Newton, en la física se alejan de ciertas soluciones escolásticas.

De todas maneras, la construcción monolítica tradicional no se libró de alguna crítica, como la del médico y filósofo Jeroni Palou (+1782) el cual expresaba que la filosofía debía desengancharse de la teología ${ }^{34}$ y el sobrino del obispo Bernat Nadal, Antoni Oliver Nadal (1770-1842) pidió que se abandonan el espíritu de escuela y los argumentos de autoridad ${ }^{35}$. No se recata de mostrarse seguidor de Leibnitz y al mismo tiempo preferir en algunas cuestiones a los cartesianos. Su maestra es la verdad.

Acaba el s. XVIII con una aceptación general de la filosofía de la experien$\mathrm{cia}^{36}$. El reconocimiento del retraso respecto de Europa era manifiesto. Pero había espíritus que no se resignaban a mantenerse desconectados del mundo exterior.

\footnotetext{
31 MARTíNeZ AlBIACH, Alfredo: «Fe y razón entre dos concordatos (1753-1851)», en ANDRÉs MARTíneZ, Melquíades, (director): Historia de la teología española, II, Desde fines del siglo XVI hasta la actualidad, Madrid, Fundación Universitaria Española - Seminario Suárez, 1987, p. 443.

32 Ibid.: pp. 452-455.

33 Piña Homs, Román: Del Decreto de Nueva Planta a las Cortes de Cádiz, en MasCaró PaSARIUS, José, (Coordinador): Historia de Mallorca, II, Palma de Mallorca 1975, p. 354, ignora esta apertura de una parte muy representativa del lulismo hacia el exterior.

34 TRIAS MERCANT: Historia del pensament a Mallorca. [I]:, p. 241.

35 Véase El verdadero filosofismo en defensa de la religión, que para confusión de los libertinos da á luz un filósofo liberal, Palma, Imprenta de Buenaventura Villalonga, 1813, $4^{\circ}$., y Carta de un filósofo moderno a un peripatético, manuscrito; cf. BOVER: II, $\mathrm{n}^{\circ}$. 836,I y XI, pp. 28 y 29 respectivamente.

36 Truas Mercant: Historia del pensament a Mallorca. [I] p. 242. Palou es autor de Aprovacion apologética que hace el Licenciado Gerónimo Palou, maestro en artes y candidato de medicina, á la disertación médico-práctica en el que Licenciado Juan Bautista Mas Alumno assi mismo de medicina ventila esta question: An resolutiones, quas perillustre, ac sapintissimum Medicinae collegium, tanquam saluti publicae infensas declaravit, citra aegrotantium incommodum possint permitti. Palma. Imprenta de Miguel Cerdá y Antich, s. a., $4^{\circ}, 30$ pp., Cf. BOVER: II, $\mathrm{n}^{\circ} .879$, p. 55.
} 
No conocemos que se haya explicado por qué, sólo en el plazo que media entre el septiembre de 1782 y febrero de 1788 y según la sola información que nos proporciona el Dr. Fiol, 80 catalanes se graduaron en teología en la Universidad de Mallorca. Algunos de ellos eran familiares de los obispos o parientes de los mismos. También obtuvieron el título médicos y juristas. ¿Esto se debió solamente a que eran admitidos directamente al examen de grado, sin escolaridad, como lo da a entender la Orden del Consejo de Castilla, comuni-

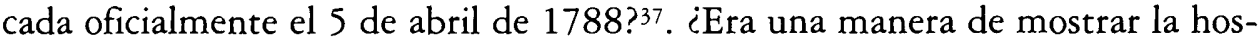
tilidad a la Universidad de Cervera? ${ }^{38}$ Posiblemente también esto signifique que la decadencia de esta centro había trascendido ${ }^{39}$. Siguiendo al Dr. Joaquim Fiol, deducimos que los mallorquines graduados contemporáneamente fueron muchos menos y solamente aparece el nombre de algunos menorquines y de muy pocos ibicencos.

No podemos cerrar esta sección sin una especial mención del P. Bartomeu Pou i Puigcerver (1727-1802). Es considerado como el introductor de la historiografía filosófica en el mundo hispánico. Se declara compatriota de Ramon Llull -populari meo- y cercano a Lluís Vives, aunque en el catálogo parcial de su biblioteca no podamos hallar la entrada de las obras de estos autores, pero sí algunas del lulista abad Pasqual ${ }^{40}$.

Llegados a este punto, podemos decir que resulta muy arriesgado concluir que el panorama del pensamiento filosófico y teológico había cambiado en sus líneas generales. El lulismo abarcaba una parte del pensamiento. Algunos de los autores que hemos citado tuvieron sólo una parcela de influencia. Diríamos que la conclusión que podríamos sacar deja en claro que el predominio de la

37 PONS, Antoni: Dietari del Dr. Fiol. Memories de Don Joaquim Fiol, de Mallorca, Doctor en Drets, que comprenen de l'any 1782 fins en 1788, Ciutat de Mallorca, Publicacions de la Societat Arqueològica Luliana, 1933, II, p. 310: "Junta a les 3 de la tarde dels 4 Collegis, en que se ha llegit carte del rey y Ofici del Sr. Regent, que es sobre lo mateix. En susbstancia, no vol el rey que los graus se conferesquen ab la facilidat, de que queda enterat el Consell. Se ha acordat son cumpliment, fent yo cap y tambe el canonge Lobo». El canónigo Francesc Ferrer, ya el día 2, entrada la noche, en secreto había comunicado al Dr. Fiol esta medida. Algún dia se confería el grado de teología a dos catalanes; supuestamente influía el interés de facilitarles el retorno a su hogar. Por esto, o se sucedían las sesiones o se distribuían entre mañana y tarde.

${ }^{38}$ No podemos ser muy precisos; pero parece que los catalanes graduados en teología pertenecían a todos los obispados catalanes, exceptuados los de Lleida y Solsona, muy cercanos a Cervera. Ahora bien, de muchos de ellos no costa el obispado de origen. Francesc Rul-lan i Garí, en su graduación prorrumpió con una invectiva contra la Universidad de Cervera.

${ }^{39}$ Con la expulsión de los jesuitas, la Universidad de Cervera entró en una etapa de decadencia, cf. BATLLOR, Miquel: L'Universitat de Catalunya a Cervera 1717-1842, en Id.: Cultura e finanze. Studi sulla storia dei gesuiti da S. Ignazio al Vaticano II, Roma Storia e Letteratura, Raccolta di studi e testi, 158.- Edizioni di storia e letteratura, 1983, pp. 279-282.

${ }_{40}$ FONT JAUme, Alexandre: «La biblioteca del P. Bartomeu Pou», en BSAL, 52 (1996) 315-338. 
escolástica ${ }^{41}$, impuesta también por voluntad real, no avasalló. No debemos crearnos una visión monolítica. Aquella construcción acusó algunas grietas.

\section{El lulismo y el «Col·legi de la Sapiència»}

El año 1595 es significativo, porque se incoaron las gestiones para lograr la canonización de Ramon Llull.42 Para promoverla, el año 1610 se fundó la "Causa Pia Lul-liana». En la Universidad Literaria surgieron serios defensores de las doctrinas del Beato. Hicieron necesaria esta vindicación los catálogos de obras antilulistas que se hicieron por indicación del inquisidor Nicolau Eimeric $^{43}$. A pesar de los esfuerzos del franciscano Antoni Busquets $(+1616)$ la posición del Santo Oficio en Roma se endureció, hasta el punto que el Inquisidor General de España prohibió las obras de Llull. La popularización de las polémicas entre las diversas facciones nos ha dejado panfletos curiosos, ingeniosos y, a menudo, insultantes.

No es nuestra pretensión entrar en el estudio del lulismo en sus diversas escuelas. Ni siquiera describiremos el influjo que Ramon ejerció en la idea que Godfried Wilhelm Leibnitz (1646-1716) se hizo sobre el arte combinatorio ${ }^{44}$. Simplemente nos referiremos a la vitalidad que esta corriente de pensamiento supo demostrar en los ss. XVII-XVIII.

Una ingente labor, llevada a cabo por el franciscano menor, natural de Maó, Francesc Marçal, se halla en estrecha dependencia de la defensa que se

41 VILANOva, Evangelista: Història de la Teologia cristiana. Vol. III. Segles XVIII, XIX i XX, Barcelona Col-lectània Sant Pacià, $N^{\circ} .41$ - Facultat de Teologia de Catalunya. Editorial Herder, 1989, pp. 186-188.

42 Puede verse lo que anotamos en Història de l'Església a Mallorca. Del Barroc a la Il'lustració, pp. 167-171.

${ }_{43}$ Además de l'obra de EIMERIC, Nicolau: Dialogus contra lullistas, editada per Jaume DE PUIG I Oliver, en Arxiu de Textos Catalans Antics, 19 (2000) 141-234, dentro de su artículo El «Dialogus contra lullistas» de Nicolau Eimeric, Ibid. pp. 7-296. Este editor acaba de traducir al catalán este escrito con el título Diàleg contra els lul-listes, Nicolau Eimeric, Barcelona, Quaderns de la crema. Assaig 34 2002, tengamos en cuenta dos obras significativas, porque van a las raíces de las acusaciones de heterodoxia contra el Beato Ramon. MADRE, Alois: Die theologische Polemik gegen Raimundus Lullus. Eine Untersuchung zu den Elenchi auctorum de Raimundo male sentientium, (Beiträge zur Geschichte der Philosophie und Theologie des Mittelalters. Neue Folge, Band 11) Münster 1973 y Perarnau I ESPELT, Josep: De Ramon Llull a Nicolau Eimeric. Els fragments de l'Art amativa de Llull en còpia autògrafa de l'inquisidor Eimeric integrats en les cent tesis antilul-lianes del seu Directorium Inquisitorum. (Conferència pronunciada en l'acte acadèmic de la festa del beat Ramon Llull a la Ciutat de Mallorca el 27 de novembre del 1997) Barcelona- Ciutat de Mallorca, Facultat de Teologia de Catalunya Centre d'Estudis Teològics de Mallorca, 1997. Perarnau ha demostrado cómo Eimeric falsificó, al menos, algunos textos de Llull. Los manuscritos que ha manejado no dan la obra completa del inquisidor, por lo que las conclusiones no se pueden generalizar a lo desconocido.

44 CARRERAS ARTAU, Tomás y Joaquín: Historia de la filosofía española. Filosofía cristiana de los siglos XIII al XV, II, Madrid 1943, pp. 304-320.

Hispania, LXII/3, núm. 212 (2002) 907-956 
hacía de Llull en Roma. Su trayectoria casi se prolonga tanto como el s. XVII, puesto que la muerte le visitó en el convento de Sant Francesc de Palma, cuando el año 1688 había cumplido los 97 años. Su pretensión fue depurar la obra luliana de las adherencias que durante el s. XVI habían recargado y desfigurado el texto del Beato Ramon Llull ${ }^{45}$. A esta tarea unió otra, con pretensiones más estrictamente científicas, al plantearse el objetivo de abrir el pensamiento luliano a las corrientes intelectuales contemporáneas, en especial pretendió confrontarlo con la obra del cisterciense madrileño Juan Caramuel de Loblokowitz, de modo particular con sus innovaciones en la lógica ${ }^{46}$.

Por otro sendero paralelo se encaminó el jesuita Jaume Custurer, cuando el año 1700 dio a luz las Dissertaciones históricas del culto immemorial del Beato Raymundo Lulio. Desde el punto de vista científico llegaba a un hito importante, puesto que se trataba de uno de los asuntos más cuestionados por los antilulistas. Pero, conviene retenerlo, los materiales contra Llull se habían acumulado en demasía, para que estos mallorquines lograran hacer valer sus argumentos, de modo que la causa que defendían entrara por vías de un razonable entendimiento, como sería de esperar de personas que trabajan sin pasión. Y no podemos decir que el calor faltara en ambos bandos. Los antilulistas trabajaban sobre unas bases distorsionadas, nada menos que por el inquisidor Eimeric, como ha demostrado Perarnau ${ }^{47}$. Este historiador de la teología, y editor de numerosos manuscritos lulianos, ha podido mostrar como Eimeric manipuló textos de Llull, de manera que pudieran ser tachados de heterodoxia. Y, en el s. XVIII, Eimeric era básico para los antilulistas, en buena parte pertenecientes al conservadurismo dominicano, que acusaba al lulismo de racionalismo ${ }^{48}$.

Teniendo esto presente, nada extraño resulta que el siglo XVIII fuera fecundo en la reflexión filosófica y teológica que provocaba el lulismo, de manera que como acaba de escribir Trias Mercant, «El lulismo no es un simple episodio; es el trasfondo, positivo o negativo, de todo el pensamiento científico y teológico mallorquín y también de gran parte del comportamiento socialmente popular» ${ }^{49}$. El eclecticismo filosófico, del cual hemos hablado, será la característica del lulismo que se cultivará desde el «Col-legi de la Sapiència».50

45 Un catálogo de las obras de Marçal se encuentra en BOVER: I, nº. 680, pp. 470-472.

46 Trias MerCant, Història del pensament, I, pp. 193-203 y, especialmente su artículo «Llull en su época y en la época moderna. La síntesis del P. Marzal», en Espíritu, 15 (1966) 141-171.

47 Cf. la obra que citamos en la nota 43 . Hasta la supuesta bula de Benedicto XI contra Llull podría ser una superchería del mismo inquisidor, Eimeric, puesto que los expertos de Benedicto XIV no lograron encontrarla, como tampoco se ha identificado hasta hoy. Este hecho hubiera podido moderar las ironías con las que, desde el poder, hirió al abad Pasqual, del cual hablaremos. Le aludía porque no había consultado una obra que, a su juicio debía de haber consultado.

48 Ibid.: p. 230

49 Trias MerCant, Sebastià: «Les claus de la Il-lustració mallorquina», Afers. Fulls de recerca $i$ pensament, 30 (1998) 298. Hemos traducido el texto del autor.

so Sobre la libertad de escuela de este colegio mayor, véase lo que decimos en Història de l'Església a Mallorca. Del Barroc a la ll-lustració, pp. 161-162. 
Este panorama cultural mallorquín tuvo que remontar obstáculos no estrictamente científicos. La autoridad real, que en parte pretendía una reforma a partir del tomismo, tuvo su brazo eclesial más eficaz en algunos obispos. Entre los más obsequiosos hemos de contar al jerezano D. Juan Díaz de la Guerra. De entrada consideraba ilícito el culto secular del beato mallorquín. Su tónica era más la de un regalista que la de un obispo. Obedeció al rey como detentor del poder en un estado absoluto. No solamente combatió el lulismo como pastor de la Iglesia en Mallorca, sino que también le declaró la guerra en el campo universitario. Con tal objetivo, en tiempos en los que no podía sostener el pequeño seminario diocesano, prefirió invertir sumas ingentes en la edición mallorquina de la Summa Theologiae de Santo Tomás de Aquino. El proyecto quedó inconcluso, con el volumen quinto, puesto que Carlos III prefirió la tranquilidad del reino, a la conflictividad suscitada por su fiel obispo, y lo trasladó a Sigüenza. El poder absoluto es el más propenso a sucumbir ante el miedo.

Una parte de los obispos se guiaba por el Consejo de Castilla que, por el octubre de 1767 , les había cursado una circular, para que reprimieran los abusos y las supersticiones. De la Guerra, en consecuencia, prohibió que el nombre de Ramon pudiera admitirse como nombre de pila, y multó a los párrocos que lo permitieron $^{51}$, y, en estos casos, no aprobaba los libros bautismales. Las imágenes y pinturas de Llull debían sacarse de los templos. Todavía queda alguna expuesta en su antiguo lugar, con la tela rasgada por orden episcopal. La inanidad científica de la obra de Custurer es patente, ante la presión del obispo obediente al rey.

Los ataques al lulismo desde el punto de vista intelectual vinieron de parte del benedictino Benito Jerónimo Feijoo Montenegro, que creía que mantener el lulismo era una manera de hacer regresar el país hacia una época periclitada. Él trabajaba eficazmente en un proceso de europeización, en un momento en el cual se había entrado por las vías científicas de la experimentación. En esto Bonaventura Serra, del cual hablaremos, se declaró discípulo del monje. Desde su ambiente, Leibnitz no rechazó tan fácilmente como Feijoo las aportaciones de Llull. Por otro lado, los lulistas más cualificados, aunque no alcanzaran la categoría del benedictino gallego, no eran menos científicos. Hasta el antiguo colegial de la Sapiència, profesor de la universidad, Antoni Ramon Pasqual i Flexas (1707-1791) abad cisterciense de La Real, que en Madrid había trabado amistad con Feijoo, no sólo trabajó sobre los elementos filosóficos de Llull, sino que se interesó por sus aspectos científicos. Fruto de este interés es su obra Descubrimiento de la aguja náutica, de la situacion de América, del arte de navegar, y de

51 SABATER, Nadal, Párroco de Binissalem: [Instancia a la «Congregació de Rectors», pera que le defienda contra las novedades con las cuales le condenan por que impone el nombre del beato Ramon Llull y por que tiene sus imágenes en el templo parroquial; sin datar $=1776 \mathrm{l}$ en «Congregación de Rectores de la Diócesis de Mallorca», Biblioteca dels Missioners dels Sagrats Cors del Monestir de La Real, Ms I-133, f. 495.

Hispania, LXII/3, núm. 212 (2002) 907-956 
un nuevo método para el adelantamiento en las artes y ciencias. (... $)^{52}$. Pasqual, mediante el jesuita Francesc Xavier Lampilles, conoció la obra del otro miembro de la Compañía de Jesús, el alicantino expulsado a Italia, Joan Andrés i Morell, Dell'origine, progressi e stato attuale d'ogni letteratura ${ }^{53}$, de quien asimiló el concepto enciclopedista de la literatura, distinguiendo las disciplinas propiamente literarias, las humanistas, científicas y especulativas. Con esta sistematización quiso emprender su aplicación a la literatura mallorquina. ${ }^{54} \mathrm{La}$ diferencia entre Feijoo, reformador, y los lulistas, más bien restauradores, estriba en que el primero tiene un punto de vista científico, basado en la razón empírica, lo cual le enfrenta con los que protagonizan la razón teórica e histórica.

En efecto, los lulistas practicaban una crítica histórica rigurosa, para llegar a lo que en realidad era patrimonio de Ramon Llull, con lo cual lo liberaban de atribuciones que le eran ajenas. Como ha escrito Trias Mercant: «la intención fundamental del lulismo del siglo XVIII es convertir Llull en un doctor universitario» $\$ 5$. Por un lado, revisan la vida y las obras del beato ${ }^{56}$ Ramon, en vistas de lo cual hubieron de servirse del utillaje hermenéutico moderno, tarea que llevó a cabo el profesor de la universidad, Pasqual i Flexas, que publicó en cuatro volúmenes sus vindicaciones de Llull ${ }^{57}$. En otro frente, Andreu Oliver introdujo el lulismo en la Facultad de Medicina de la Universidad Literaria. Por esto, cabe reconocer que la acusación de antiilustrado, que levanta Feijoo contra el lulismo, carece de apoyo, aunque haya que coincidir con él en el sentido que el lulismo no satisfacía las exigencias de la modernización de España desde el punto de vista científico-experimental.

\footnotetext{
52 Madrid, Imprenta de Manuel Gonzalez MDCCLXXXIX, 4ํ, 320, pp., a parte de las dedicatorias e índice. También dejó manuscrita una Demostración del origen del sistema copernicano, sacada de. las obras del B. Raimundo Lulio. Véase BOVER: II, nº. 886, VI y X, pp. 61 y 62.

53 Parma, Dalla Stamperia Reale, 1782-1798. Puede verse BATLLORI, Miquel: Els catalans en la cultura bispanoitaliana, Obra completa, vol. X, [...] Pròleg de BENÍreZ I RiERA, Josep M., València Biblioteca d'Estudis i Investigacions, $n^{\circ}$. 27, 1998, pp. 11-15,190-203,207-214,215-229242-247; Id. Història, classicisme i filosofia al segle XVIII: Gustà, Pou i els Masdéu, vol. XI, [...] Pròleg de LLuís I FONT, Pere; $\left(\mathrm{n}^{\circ} .28\right)$ València 1998, p. 56.

54 Truas Mercant: Historia del pensament a Mallorca. [I] p. 263 y en «Les claus de la Il-lustració mallorquina», p. 307.

55 TRIAS MERCANT: Historia del pensament a Mallorca. [I] p. 225 y en «Les claus de la Il-lustració mallorquina», Afers. Fulls de recerca i pensament, (Valencia) 30 (1998) p. 298.

56 Hasta Pere Màrtir AlberTí, dominico, consideraba que en Mallorca el «Beat» por antonomasia era el Beato Ramon Llull, cf. BOVER: I, $\mathrm{n}^{\circ}$. 16, pp. 13-14.

57 Vindiciae Lullianae sive demostratio critica inmunitatis doctrinae illuminati Doctoris $B$. Raymundi Lulli martiris, ab erroribus eidem á Nicolao Eymerico impactis, á censuris ab Albitrio Cardinali relatis; reliquisque aliorum lituris. Fundata in collatione textuum Lulli (...). I-IV, Avenione apud J. Garrigan, typ. bibliop. MDCCLXVIII, 4º I: X+439-114 ps.; II: 828 ps.; III: 411 ps.; IV: 611 . Véase, en particular, Trias Mercant, S.: Hacia una clasificación de las obras del lulista P. Pascual», en Estudios Lulianos, (Mallorca) 16 (1973)194-215.
} 
El salón de Bonaventura Serra y la correspondencia con los ilustrados españoles y franceses

Hemos de enumerar a los mallorquines que mantuvieron una puerta abierta a las nuevas ideas, a través de una correspondencia con los preilustrados de la península ibérica y, más aún con los franceses. Un caso notable es el de Bonaventura Serra (1728-1784) hijo de una familia profundamente religiosa y educado por una de las denostadas escuelas de los franciscanos. Entró en el clero con la tonsura el año 1741. Estudió Cánones y los enseñó después durante ocho años. En unas notas autobiográficas, se proclama adicto a la religión y a la Iglesia ${ }^{58}$. Pero esta fidelidad no fue óbice para que intercambiara correspondencia con Voltaire y, además, para que manifestara su admiración por Rousseau y D'Alembert. ${ }^{59}$ Aun habiendo salvado su integridad católica, hubiera recibido la crítica del Menéndez Pelayo de la Historia de los Heterodoxos Españoles, que acusa a personas que se mantuvieron en la misma tesitura de Serra, a pesar de sus contactos con los iluminados. No olvidemos que la Inquisición en Mallorca seguía vigilante. Una denuncia que se hizo llegar a la Suprema, contra un militar francés, que leía las Confesiones de Rousseau, por el año 1786, tuvo resultados expeditivos ${ }^{60}$. Estas lecturas se generalizaron, de manera que alguien escribió que casi todos los españoles de algun viso estaban contaminados de las doctrinas de las doctrinas de los filósofos franceses, sobre todo de las funestas de Voltaire y de Rousseau ${ }^{61}$.

En la época del barroco la burguesía y los aristócratas empezaron a configurar grupos de convivencia, en los cuales se daba el intercambio de ideas, la lectura en voz alta y la correspondencia con personas que compartían una misma inquietud.

Éste es el caso de Serra. Se cartea con el historiador Enrique Flórez, con Martín Sarmiento, con Gregori y Joan Maians i Ciscar y se propone seguir el método de Feijoo ${ }^{62}$. Está interesado en que sus escritos se difundan en el extranjero, para lo cual pide al primero de los Maians que trabajen en ello63.

En su saloncito no sólo se reunían las personas más cultas de Palma, sino que también recalaban allí los viajeros más notables que llegaban a la isla ${ }^{64}$. Al

58 Pons: El Dr. Fiol, II, p. 434.

59 PONS: El Dr. Fiol, I, pp. XXX-XXXIV; Oliver, Mallorca durante la primera revolución, 33. Casos semejantes en la Península, se pueden ver en Jean SARRAILH, La España Ilustrada de la segunda mitad del siglo XVIII, Madrid Fondo de Cultura Económica, 1957 (cuarta reimpresión: 1992) pp. 309-321.

60 SARRAIlH: La España, p. 299.

${ }^{61}$ GuASP Pou, Felipe: «El Dr. D. José Barberi» (Continuación) III, en BSAL (Mallorca) 21 (1926-1927) 87.

62 Cf. TRIas MERCANT: «Les claus de la Il-lustració mallorquina», p, 307.

63 PeSET I LLORCA, Vicent: Gregori Mayans i la cultura de la Il·lustració. Pròleg d'Antoni Mestre. Barcelona - València, Documents de Cultura, 5.- Curial.- Tres i Quatre, 1975, pp. 221-222.

64 OLIVER: Mallorca durante la primera revolución, 33; SUREDA BLANES: Petites histories, p. 24. 
estilo de la época, emprende una obra de carácter apologético, todavía por estudiar con detenimiento, que le conducen a afirmar la dignidad de su pueblo y de su lengua, en el gran concierto del mundo de su tiempo ${ }^{65}$. Josep de Pueyo fue uno de estos contertulios de Serra ${ }^{66}$, y al mismo tiempo compartía con él algunas de aquellas amistades que hemos mencionado y ambos se atrevían a hacer incursiones en la arqueología, la historia, la pintura, la botánica, la química, etc. ${ }^{67}$

\section{La Sociedad Económica Mallorquina de Amigos del País}

Del salón del barroco, en la segunda parte del s. XVIII, se tiende a la institucionalización. Así en Mallorca se pasó a la creación de la SEMAP. Sus características no difieren de las entidades que le son anteriores o contemporáneas. Habría que revisar los datos sobre la presencia de eclesiásticos en esta sociedad, señalando con precisión si eran de Palma o de la Part Forana (el resto de la isla de Mallorca) dato que sería un buen indicador de la incidencia extensiva de las nuevas ideas.

En una lista manuscrita de 1786, que vio Miquel dels Sants Oliver, solamente eran 6 los eclesiásticos inscritos ${ }^{68}$. Otro catálogo de socios, impreso el año 1784 , sobre 111 inscritos, nos informa que 14 eran eclesiásticos, entre ellos se encontraban el pío obispo Pedro Rubio Benedicto, el abad cisterciense de La Real, algunos canónigos, varios párrocos y diversos superiores de órdenes religiosas. En otro elenco de 1799, sobre 109 socios la proporción de los eclesiásticos había subido a $29^{69}$; la mayoría del resto pertenecía a la nobleza y al estado militar o ambos, porque la burguesía no existía apreciablemente ${ }^{70}$. De la devoción de esta entidad tenemos una muestra en que acababa las sesiones con el canto de la Salve ${ }^{71}$.

Es significativo que, mientras los acontecimientos sangrientos de Revolución francesa, entre otros factores, contribuyen a suscitar un estado de miedo de la sociedad y de los eclesiásticos en particular, por otro lado los clérigos ins-

65 Amengual i Batle, Josep: «Nova documentació sobre la imposició del castellà a l'ensenyament del catecisme a la Seu de Mallorca, maig 1773-gener 1779», en Fontes Rerum Balearium (nova etapa) (Mallorca) 1 (1990) pp. 192-194.

66 Ibid.: p. 193 :

67 OLIVER: Mallorca durante la primera revolución, pp. 27-34, sobre Serra y Pueyo.

${ }^{68}$ OLIVER: Mallorca durante la primera revolución, p. 71 ; cf. la p. 69, nota 1, donde ofrece la fecha de la Representación de la Sociedad Económica Mallorquina de Amigos del País, que es del 23 de octubre de 1786. Véase la p. 42, sobre la participación del clero en los inicios de esta Sociedad.

69 Señores Socios de la Real Sociedad Ecónomica Mallorquina existentes el dia de la fecha, 1 de gener de 1799, firmado por el secretario Josef Zanglada de Togores.

70 VICENS VIVES, Jaime: Aproximación a la Historia de España, Barcelona ${ }^{8} 1974$, (primera reedición) p. 146.

71 SARRAIlH: La España, p. 273. 
critos en la Sociedad aumentan. Posiblemente debamos distinguir entre el interés por el progreso técnico, por el esfuerzo para contribuir a la felicidad del pueblo, con lo que no se mudaba la situación ideológica ni se ponía en seria discusión el orden social y político, y las ideologías que incidían en la alborada de un nuevo orden de la sociedad y de la Iglesia.

No sabemos cuál fue la incidencia de los presbíteros franceses, que llegaron a Mallorca, fugitivos de las represiones de la revolución ${ }^{72}$. Este hecho tal vez pudo contribuir a acrecentar la hostilidad a las ideas francesas. Por supuesto, la prevención contra ellas fue objeto de escritos y sermones ${ }^{73}$.

\section{Un obispo liberal y un canónigo afrancesado}

Queremos mencionar otras dos personas, con trayectoria en parte coincidente, pero muy dispares en su tónica general. Se trata del obispo Nadal y del tonsurado, Cladera, que fue canónigo tesorero de Mallorca, parlamentario de Bayona y colaborador cercano del fugaz José Bonaparte. Son los dos eclesiásticos mallorquines que pueden ser considerados pertenecientes a la ilustración y hasta liberales.

\section{El obispo de la Constitución de Cádiz}

La trayectoria del obispo Bernat Nadal i Crespí (1745-1818) establece el puente entre dos siglos y, más aún, representa la transición entre dos épocas. Su formación es totalmente mallorquina, con una fuerte dosis de lulismo. Después de un sexenio de trabajo parroquial pasa a $\mathrm{Madrid}^{74}$, donde obtuvo el car-

72 Cf. FAJARNÉS TUR, Enric: «Emigración de sacerdotes franceses a al isla de Mallorca en 1792", en BSAL, (Mallorca) 7 (1897-1898) 398-399 trae una lista de 35 presbíteros franceses, la mayoría de Languedoc, llegados el 13 de octubre de 1792. El autor considera que a su fuente posiblemente faltaran los cuadernillos con los datos de algunas barriadas de Palma. Cf. OLIver, Mallorca durante la primera revolución, pp. 97, 117-121. Cf. ROURA I AULINAS: L'Antic Règim a Mallorca, p. 49, cita la Liste des émigrés et prêtres réfractaires qui ont résidé aux îles de Minorque et Mayorque, del Archive National de Paris, $\mathrm{F}^{7}$ 3.332, dossier 2, que se puede consultar en fotocopia en el Arxiu del Regne de Mallorca, sección «Diversos - Fons D. A. Lestapis, signatura 1/1.

73 Cf. QUINTANA I TORRES, A.: "Vicis, costums y solidaritats de la menestralia mallorquina del segle XVIII", en Afers. Fulls de recerca i pensament, (Valencia) 23/24 (1996) 243-254; cf. un paralelismo, muy conocido, en fray Diego José de Cádiz, en EGIDO, «El regalismo», pp. 246-247.

${ }^{74}$ Nicolau i BaUzÀ, Josep: «Un antic collegial de la Sapiència: El bisbe de Mallorca, D. Bernat Nadal», en Comunicació. Revista del Centre d'Estudis Teològics de Mallorca, (Mallorca) 40-41 (1985) pp. 47-48; da algunos datos de la etapa previa a la salida de Nadal a Madrid. Creemos que tiene razón el autor cuando muestra que es inexplicable el silencio sobre Nadal que mantienen los historiadores de las Cortes, sea desde el punto de vista general, como desde el de un historiador de

Hispania, LXII/3, núm. 212 (2002) 907-956 
go de penitenciero y limosnero, en la iglesia de San Isidro, cuyo cabildo tenía fama de ilustrado y regalista ${ }^{75}$. Llegó a presidir una institución de orientación jurídica, o sea la Real Academia de la Concepción. Regresó a su tierra, después de quince años de servicios como traductor al servicio de la Corte, una vez que en 1794 fuera postulado por el Ayuntamiento de Palma como obispo de Mallorca. Un siglo después se reiteró una postulación semejante a favor de PereJoan Campins i Barceló (1898-1915).

Las tendencias regalistas llevan a Nadal a propugnar un cambio en el procedimiento de los nombramientos de los cargos eclesiásticos, de manera que, según él, deberían depender a la voluntad real. Su acatamiento al decreto de 5 de septiembre de 1799, de Carlos IV, en el cual se prescribía que los «obispos usen de la plenitud de sus facultades, conforme a la antigua disciplina de la Iglesia», fue manifiesto. Nadal respondió:

Ejecutaré gustosísimo y sin la menor dilacion cuanto se espresa, tocante á mí, en la enunciada soberana resolucion del dia 5; y en verdad en esta parte, supuesto el beneplácito de S. M., obraré por principios y conviccion; y por consiguiente, poco mérito creeré $[\ldots .$.$] , contraer [...] en adoptar y practicar una doctrina que por$ espacio de doce siglos, y hasta que la ignorancia triunfó de la verdad, tuvo adoptada toda la iglesia católica ${ }^{76}$.

Es el «nonato e inexistente» ${ }^{77}$ cisma de Urquijo, que, en realidad, encontró muy poca resonancia ${ }^{78}$, de manera que se puede decir que Nadal fue uno de los pocos obispos que se hicieron eco del decreto real.

\footnotetext{
la Iglesia. Omitimos alguna referencia más concreta que leemos en su nota preliminar, p. 47. Por otra parte, el enfoque de este artículo no es global.

75 Revuelta GonZÁlez, Manuel: Política religiosa de los liberales en el siglo XIX, Historia de España en el mundo moderno, 4, Madrid (CSIC) 1973, p. 26, nota 69.

76 LLORENTE, Juan Antonio: Coleccion Diplomatica de varios papeles antiguos y modernos sobre dispensas matrimoniales y otros puntos de disciplina eclesiástica. (Imprenta de D. Tomas Alban y Compañía) Madrid ${ }^{2} 1810$, Núm. 40, p. 164 . El texto del decreto y de la respuesta del obispo de Mallorca se puede ver en MenÉndez Pelayo: Historia de los Heterodoxos Españoles, II, pp. 466 y 468, respectivamente. Advirtamos que Duran: Bernat Nadal, p. 77, nota 5, dice que Mn. Antoni Pons dudaba de la autenticidad de esta carta. No sabemos en qué se basaba. Para darle razón habría que probar que la capacidad de manipulación de Llorente llegara a retar a los obispos. Tengamos en cuenta que la segunda edición que citamos, es anterior en varios años a la muerte de Nadal. Y no nos consta que protestara por la publicación de su carta, cuyo contenido era aceptable para sus amigos de Cádiz. Con todo, resulta extraño el silencio de Menéndez Pelayo sobre la Constitución de Cádiz, y el papel de Nadal. En conversación con el Prof. Miquel Duran, el 29 de junio de 2000, pude entender que tiene motivos para no dar tanta fuerza a la opinión de Mn. Pons. NiCOLAU i BAUZÀ: «Un antic col-legial de la Sapiència», p. 52, conoce y rechaza este decreto, pero parece ignorar la respuesta de Nadal.

77 EGIDO, Teófanes: El regalismo y las relaciones Iglesia-Estado en el siglo XVIII, en GARCíaVilloslada: Historia de la Iglesia en España, IV, p. 213.

78 SIERRA NAVA, Luis: La reacción del episcopado español ante los decretos de matrimonios del ministro Urquijo de 1799 a 1813, Prólogo de José F. DE LEQuERICA, Bilbao Publicaciones de la Facultad de
} 
Se ha observado que Nadal se muestra tibio en su aprecio del papado ${ }^{79}$. Es bien posible que fuera así; creemos que hemos de considerarle regalista, aunque consideramos prematuro clasificarle como jansenista, en el sentido que se da al término, al referirse a su deseo de renovar de la Iglesia mediante la restauración del poder episcopal. La tibieza dice relación a frío y calor y la sensación por sí misma no nos precisa el grado de la temperatura, ni tampoco la sensación determina si el grado percibido es el adecuado. Al fin y al cabo se trataría de un juicio de tipo moral, que queremos eludir, porque pertenece a otro orden de cosas. Por esto, preferimos considerarlo como regalista, porque, lo que sabemos es que Nadal se acogió a una tradición antigua, en cuanto al ejercicio del episcopado. Las pretensiones que se manifestaban en este sentido en el s. XVIII estaban suficientemente fundadas en la Escritura y en la tradición. Lo que no percibió Nadal y que, en cambio, tuvo muy presente el mencionado concilio, fue que el cauce estaba envenenado por el lastre secular de la intromisión de los poderes civiles en la economía y jurisdicción eclesiásticas. Por esto, su apelación a la antigua disciplina de la Iglesia es parcial. La verdaderamente antigua ignora por completo el poder civil y varias veces el Evangelio dice taxativamente que no hay que imitar a los poderes del mundo que dominan (cf. Mc 10,42-45- Mt 20, 25-28). Decir que en tiempos de Nadal estos poderes se habían vuelto muy opresores, no es más que etiquetar lo que presentamos tan rápidamente aquí. Sea lo que fuere, consideramos inadecuado calificar a este obispo de jansenista, tanto más cuanto, en un contexto quizá más próximo a esta corriente, se prefiere utilizar un calificativo más atenuado, el de parajansenista ${ }^{80}$. Estudios más globales de los escritos de Nadal quizá nos llevaran a otra valoración.

Por otra parte, lo que nos falta dilucidar es de qué fuente bebía Nadal. Posiblemente le contagiaran corrientes regalistas, de antigüedad preborbónica. También se vislumbran líneas episcopalistas, con tendencia a aproximarse a las corrientes de los ilustrados. Su entorno en la Corte pudo contribuir a ello. El trabajo que realizó en el estudio de la Escritura pudo también influir en el afán de simplificar y acercar el ministerio a la iglesia local. No queremos caer en la tentación de explicarlo todo apelando a lo que Appolis ha llamado el tercer partido jansenista ${ }^{81}$. De todas maneras, Nadal debió llegar a compartir ideas

\footnotetext{
Filosofía y Letras de la Universidad de Deusto, 1964, pp. 44-45; EGIDO, «El regalismo», pp. 247 248; CORTS I BLAY, Ramon, L'arquebisbe Fèlix Amat (1750-1824) i l'ultima Il-lustració espanyola, Barcelona, Col-lectània Sant Pacià, No. 44 - Facultat de Teologia de Catalunya. Editorial Herder, 1992, p. 21.

79 TRIAS MERCANT: Història del pensament, [I] pp. 272-273 y, «Les claus de la Il-lustració mallorquina» p. 304.

80 CORTS I BlaY: L'arquebisbe Fèlix Amat, p. 5.

81 Cf. el capítulo X: «Le systheme «Tiers Parti» de l'archévêque Amat (1799-1824) de Émile APPOLIS: Les jansenistes espagnols, (Sobodi) Bordeaux 1966, pp. 174-203. La advertencia de proceder
} 
más críticas. Appolis nos hace ver cómo, en su residencia de Cádiz, Joaquín Villanueva exponía sus ideas acerca de los concilios provinciales, y se lamentaba por la decadencia en que habían caído. Las razones a las que alude son históricamente verificables ${ }^{82}$. Una de ellas radicaba en el tipo de rey, que se impuso con el tiempo, al cual, como hemos leído, acataba por principio y por convicción.

Tengamos presente que al modelo de rey absoluto le correspondía la configuración del modelo del obispo cada vez menos ligado a decisiones colegiales. De hecho, en la historia sinodal de Mallorca, hay un vacío que cubre por completo los ss. XVIII y XIX ${ }^{83}$, a caballo de los cuales se desarrolla el período episcopal de Nadal. Las razones que dan los obispos del siglo XVIII apuntan que, a veces, los impedimentos vienen del intervencionismo borbónico, y, en la centuria siguiente, sus sucesores los achacan a los liberales. También se percibe una tergiversación en lo que son y significan los sínodos. Los obispos escriben a Roma que para reformar el clero y la disciplina eclesiástica no es necesario reunir sínodos, sino que basta conducir al clero a los ejercicios espirituales y otras prácticas de oración y mortificación. La eclesiología se substituye por la ascética presbiteral, no tanto por la episcopal ${ }^{84}$.

Sea lo que fuere de este asunto, las obras de los grandes jansenistas, como Zeger Bernhard van Espen (1646-1728) llegaron a Mallorca. Las hemos visto en alguna biblioteca. Queda por averiguar si se trata de algún caso excepcional.

También se pueden percibir resabios regalistas y de un cierto parajansenismo eclesiástico cuando asume actitudes intervencionistas en las órdenes religio$\operatorname{sas}^{85}$. Igualmente, da a entender que hay que recortar la incidencia de las órdenes religiosas en la enseñanza y en la sanidad ${ }^{86}$, aunque después como obispo intervendrá en la creación de instituciones religiosas dedicadas a estos fines.

con cautela, para no meter bajo el mismo epíteto a los eclesiásticos aperturistas y a los teólogos más fanáticos, la hace BATLLOR, Miquel: «L'Illuminismo e la Chiesa», p. 330.

82 ApPolis: Les jansenistes espagnols, p. 163; Serían la incuria de la Congregación del Concilio, nuevas exigencias para su ratificación, desconfianza de los reyes y autosuficiencia de los obispos. Las relaciones para visitas ad limina de los obispos de Mallorca, durante el s. XVIII, muestran que la intervención real se había hecho enojosa. Cf., también, Solís, Ramón: El Cádiz de las Cortes. La vida de la ciudad en los años 1810 a 1813. Madrid, Alianza 160, 1969, p. 3289. BATLLORI en «L'Illuminismo e la Chiesa», en Id.: Cultura e finanze. Studi sulla storia dei gesuiti da S. Ignazio al Vaticano II, Roma, Storia e Letteratura, Raccolta di studi e testi, 158.- Edizioni di storia e letteratura, 1983 , p. 330.

83 Amengual i Batle: «Tres concilis, tres models d'Església i tres estils sinodals», en $B S A L$ (Mallorca) 55 (1999), pp. 7-54, especialmente, las pp. 25-27.

${ }^{84}$ Ibid.: pp. 26-27.

85 Veny BALlester, Antonio: La Real Casa de San Cayetano de Palma de Mallorca. El P. José Mariano Talladas, C. R., Roma, Regnum Dei- Collectanea Theatina, 1971, pp. 297-299, donde se puede leer su decreto del 07-10-1795, que expresa su plan de intervención en la comunidad de teatinos de Palma.

${ }^{86} \mathrm{Cf}$. TOMSICH, $\mathrm{M}^{2}$. Giovanna: El jansenismo en España. Estudio sobre ideas religiosas en la segunda mitad del siglo XVIII, Madrid, Siglo XXI Editores, 1972, p. 93. 
Pero en este punto le regía el norte de que se debía favorecer la religión práctica, que se expresaba en la creación de institutos religiosos útiles, es decir dedicados a la enseñanza ${ }^{87}$ y a la asistencia de los enfermos, ancianos, etc. ${ }^{88}$ En este sentido dio su aprobación a la Congregación de las Hermanas de la Caridad, fundadas por Mn. Antoni Roig. Retornaremos sobre ello.

Nadal fue considerado liberal y como tal fue apreciado y rechazado, según las tendencias de quienes le valoraban. Como diputado a las Cortes de Cádiz ${ }^{89}$ tuvo la oportunidad de redactar el Discurso preliminar leído en las córtes al presentar la comisión de constitución el proyecto de ella,, 90 aunque lo leyera Agustín Argüelles $^{91}$. Éste recordará al obispo diputado a las Cortes de Cádiz que los obispos franceses habían renunciado a los bienes eclesiásticos. Nadal será uno de los pocos casos entre los obispos españoles que era consciente de ello ${ }^{92}$. Solís nos dice que, en el hogar gaditano del obispo, los diputados eclesiásticos tenían plena acogida y «se hablaba allí de religión y de filosofía en un tono no siempre moderado»93. Jaime Villanueva escribe que el Congreso encargó a Nadal las comisiones más destacadas ${ }^{94}$, y a él y a sus buenas ideas de literatura y el amor á la

87 Duran Pastor: Bernat Nadal, pp. 41-44. Nadal está a la raíz del Colegio de la Pureza de María Santísima, que posteriormente dio origen la homónima congregación religiosa.

88 DURAN PASTOR: Bernat Nadal, pp. 73-74.

89 SuÁreZ, Federico: Las Cortes de Cádiz, Madrid, Ediciones Rialp, 1982, p. 32, donde figura el nombre de Nadal en la lista de diputados.

${ }^{0}$ Palma, impr. de Agustin Roca, 1813, $8^{\circ}, 120$ pp. cf. Bover: I, nº. 794, II, p. 546; Oliver, Mallorca durante la primera revolución, p. 553. Sorprendentemente SUÁREZ, Las Cortes, p. 93, no mencionada para nada a Nadal, cuando se alude a que se comisionó a Argüelles para leer el discurso preliminar. También extraña que, en la p. 203 , se pregunte por la trayectoria de los diputados y siga omitiendo toda referencia al mismo, cuando cita, en otros lugares, a OlIVER, que da materiales para algo más. Nadal prácticamente es un ausente en este libro.

91 Por este motivo, según Duran Pastor: o. c., p. 91, Fernández Almagro, M.: Orígenes del Régimen Constitucional en España, Barcelona, Ed. Labor, 1976, p. 82, lo atribuyó a Argüelles. DuRAN PASTOR, pp. 91-95, ofrece argumentos para defender la autoría de Nadal. Mientras no haya razones sólidas en otra dirección, hay que atribuir esta pieza parlamentaria modélica a Nadal.

92 Duran Pastor: Bernat Nadal, p. 73.

${ }^{93}$ Solís, El Cádiz de las Cortes, p. 329; cf., también, Duran PaSTOR, Bernat Nadal, p. 76.

94 VillanueVA, Jaime: Viage Literario à las Iglesias de España: XXII: Viage à Mallorca, Madrid 1852, p. 161. CÁRCEL ORTí, Vicente: Política Eclesial de los Gobiernos Liberales Españolas 1830-1840, Pamplona Ediciones Universidad de Navarra, S. A, 1975, p. 13, juzga que «los convulsos años treinta fueron de capital importancia porque en ellos lograron consolidarse las bases del moderno anticlericalismo hispano, que habían sido sentadas en las Cortes de Cádiz (1812) y durante el trienio comúnmente llamado liberal o constitucional (1829-1823)». Consideramos que las raíces del anticlericalismo son más hondas, y no del todo exteriores al mismo estamento eclesial. Posiblemente los eclesiásticos moderados de las Cortes de Cádiz desactivaron muchos dispositivos anticlericales; pero su efecto fue más que compensado por la alianza entre el Trono y el Altar, que sucedió casi inmediatamente a las mencionadas sesiones parlamentarias.

Hispania, LXII/3, núm. 212 (2002) 907-956 
ilustración general que le anima, le debe que haya podido completar el viaje a Mallorca con los dos volúmenes que publicóos.

Consideraba Nadal que, en adelante, los clérigos no tuvieran una representación especial en las Cortes, como si formaran un estamento a parte ${ }^{96}$.

Coherentemente, como obispo, no permitía que los serviles, muchos de ellos inmigrados a causa de la guerra, subieran al púlpito para defender sus ideas. Para ello, Nadal recalcaba y exigía que se usara la prensa. No en vano había apoyado en las Cortes la libertad de este medio, entonces relativamente nuevo, si atendemos a su expansión.

Como liberal también atacó duramente en el foro de Cádiz a los señoríos, de manera que sostiene que se debía lograr que hubiera una única jurisdicción. Alegó contra ellos experiencias opresoras que se vivían en su ciudad natal de Sóller.

El liberalismo moderado de Nadal, como el de tantos otros, no tenía por qué llegar hasta las últimas consecuencias, en cuanto a la coherencia práctica y menos tenía por qué incluir la adopción de unas posturas de tipo filosófico que le desviaran hacia convicciones impías o ateas, que al fin y al cabo no necesariamente satisfacen los requisitos científicos últimos.

Habiendo crecido en contacto con personas marcadas por la preilustración, buscó ejercer una tarea pastoral que ayudara a depurar las prácticas religiosas de la superstición y de elementos chabacanos, aunque en esto coincidiera con las normas sinodales y hasta con las que había dictado su antecesor, Pedro Rubio Benedicto, hombre pío y nada contagiado por la Ilustración. Rubio, siguiendo una tradición muy extendida en la Iglesia, y fomentada por los sínodos y sobre todo por sus antecesores, desde principios del s. XVIII ${ }^{97}$ había promovido las conferencias de moral, los ejercicios espirituales entre el clero ${ }^{98}$, en la cual se mantuvo también Nadal99.

Sin fundamento se repite que fue innovador en su insistencia en la enseñanza del catecismo. Sí, en cambio lo fue al mandar componer el primer catecismo propiamente diocesano en Mallorca, cuyo resultado es una síntesis del que compuso el P. Diego de Ledesma, con elementos del P. Gaspar de Astete y

95 Villanueva: o. c., pp. 161-162.

96 DURAN PASTOR: Bernat Nadal, pp. 90 y 98.

97 Véanse las informaciones que recogemos en Història de l'Església a Mallorca, pp. 111-113. El tema es recurrente en PUIGVERT, Joaquim M., «L'Episcopat i la formació del baix clergat al s. XVIII. L'exemple de les conferències eclesiàstiques del bisbat de Girona», en Id. (editor): Bisbes, Il-lustració $i$ jansenisme a la Catalunya del segle XVIII, Universitat de Girona. Universitat de Vic, Eumo, 2000, pp. 89-132 y, en su obra más reciente, Església, territori i sociabilitat, Universitat de Vic. Referències 31, 2001.

98 DURAN PASTOR: Bernat Nadal, pp. 17-27, describe la acción pastoral de Nadal. Habría que precisar que muchos aspectos no son innovadores. Las visitas ad limina, las visitas pastorales y hasta los sínodos y edictos episcopales servia de antecedente y de apoyo a muchas medidas reiteradas, no originales, de Nadal.

${ }_{99}$ Edicto General de 24 de febrero de 1798. 
numerosas piezas de Ripalda ${ }^{100}$. Conviene no perder de vista estos ingredientes, para no volver a incluir esta doctrina cristiana medievalizante entre las obras de cuño preilustrado. Ningún vestigio de renovación bíblica penetró en la obra que encargó Nadal ${ }^{101}$.

Los preilustrados cristianos creían en la fuerza de la cultura, transmitida en obras que llegaran al mundo, especialmente a la minoría alfabetizada. Así, Nadal fue hombre de su tiempo cuando, sin ser muy teólogo, compuso una Historia Sagrada desde el principio del mundo hasta las ruinas de Jerusalen. Data de sus años madrileños (1779). Sigue a menudo al benedictino francés Augustin (Antoine) Calmet, (1672-1757) editor de la Biblia en francés y latín y de un diccionario histórico de la Biblia ${ }^{102}$.

Independientemente de Nadal, así lo creemos, y anterior a su citada Historia Sagrada, pero en una línea más innovadora, el año 1777 , se publicaron en Mallorca dos gruesos volúmenes, que contienen la traducción del Catecismo Histórico del levemente galicano Claude Fleury, cuya edición reducida se editó en la isla al menos 24 veces, a lo largo del s. XIX, todas en castellano ${ }^{103}$. Lo había traducido el mercedario Interián de Ayala (1656-1730) y lo había publicado en Madrid, el año $1718^{104}$. En este punto, el retraso mallorquín es patente, aún con relación a las ediciones hispánicas.

Observemos, sin embargo, que estas obras innovadoras, lo fueron en Francia con un siglo de antelación, en el caso de Fleury y con unos cincuenta años, en el caso de Calmet, antes de que repercutieran para el público en Mallorca.

100 Véase Amengual i BATLE, Josep: Llengua i catecisme de Mallorca: entre la pastoral i la política, Mallorca, Conselleria de Cultura, Educació i Esports. Govern Balear. Institut d'Estudis Baleàrics, 1991 [1992] pp. 149-152 y la lista de las ediciones, en las pp. 222- 224,234, a parte de otras ediciones readaptadas. Véase también $D$. Antoni Roig i Rexart. Peoner de la caritat i l'evangelització. Fundador de les Germanes de la Caritat, Mallorca 1987 pp. 49-50, donde explicamos la participación de Roig y de Antoni Evinent, en la preparación del catecismo diocesano, vigente hasta el concilio Vaticano II, aunque se presente bajo otros nombres o autorías, puesto que los retoques introducidos son insignificantes.

101 AMENGUAL I BATLE: Llengua i catecisme de Mallorca, pp. 194-200, donde resaltamos cómo la eclesiología de base es la de la contrarreforma y señalamos la carencia de contenido y de lenguaje bíblicos.

102 Calmet fue uno de los autores que influyeron en el P. B. J. Feijoo, cf. DelPY, G.: Bibliograpbie des sources françaises de B. Feijóo, (Hachette) Paris, 1937, 24, citado por APPOLIS: Les jansenistes espagnols, p. 24.

103 AMENGUAl i BATle: Llengua $i$ catecisme, pp. 146, 228-229, a cuya lista hay que añadir la edición de Palma, de 1857, por P. Gelabert. Véase su presencia en las bibliotecas valencianas, según LAmarCa LANGA, Genaro: La cultura del libro en la época de la Ilustración. Valencia, 1740-1808, València, Estudios Universitarios, 60. Edicions Alfons el Magnànim, 1994, pp. 68-69 y 73.

104 Cf. MESTRE SANCHIS, Antonio, Religión y cultura en el siglo XVIII español, en GarcíaVILlOSLADA: Historia de la Iglesia en España, IV, p. 649; PLACER, G.: «Interián de Ayala», Diccionario de Historia Eclesíastica de España, dirigido por Aldea VAQuero, Quintín, Tomás Marín MARTínez, José VIVES GATELL, II, Madrid, C.S.I.C. Instituto Enrique Flórez, 1972, p. 1206.

Hispania, LXII/3, núm. 212 (2002) 907-956 
Como última de las pinceladas del cuadro de Nadal, añadamos que el lenguaje de sus escritos pastorales, lo mismo que el de los edictos ${ }^{105}$ de su Vicario General y Gobernador Eclesiástico, Muntaner i Garcia, tiene un sabor nuevo, menos piadoso, más secular y religiosamente menos vigoroso.

Nadal estuvo a tiempo para experimentar como la torpe y agresiva restauración de Fernando VII deshizo las reformas. El rey actuó según los principios del regalismo, que Nadal había profesado, como hemos visto. El regalismo en boca de un obispo era un arma extremadamente peligrosa. Y Nadal la padeció. El regreso del rey aplastó toda manifestación de la libertad. Conocemos las adhesiones de Nadal al soberano. Datan del septiembre de 1814. El medio año transcurrido desde la llegada de Fernando VII, a la frontera pirenaica, era suficiente para aleccionar a cualquiera de los antiguos promotores de las Cortes de Cádiz, de forma que se enmendara y así evitara caer en el destierro o en pena superior. Nadal no entró por el camino de la heroica resistencia. Sus expresiones empedradas de términos propios de su etapa anterior, tales como mentar «la ilustrada caridad» de los párrocos ${ }^{106}$, para que vigilen el menor movimiento disidente y que se lo denuncien cada semana, no deja de ser un sarcasmo. La escuela de los ilustrados no conducía necesariamente al heroísmo. La alternativa que le quedaba era la de sacar partido de los recursos menos comprometedores y estar a la espera de tiempos mejores. De todas formas un espíritu mediterráneo supo sacar de su experiencia instrumentos contemporizadores y, en circunstancias tan violentas, las palabras dirigidas al tirano tienen el valor que tienen, hasta pueden revestirse del sentido contrario de lo que dicen literalmente. Nada fácil es pasar por la estricta hermenéutica esta exhortación, sacada de su aviso publicado en el Diario de Mallorca, el 7 de septiembre de 1814:

Procurar en el púlpito, en el confesionario y en sus conversaciones familiares rectificar cualquier opinion poco conforme á nuestra Santa religión, á la mencionada soberania e independencia de Fernando VII, á la subordinación y sabio respeto a su sabio gobierno, á la conservación y tranquilidad del Estado y á la mas sana moral 107 .

El espíritu que inspiró a Nadal no se evaporó por completo. Los elogios que se pronunciaron con ocasión de su muerte no siempre respetan la sencillez cristiana, ni los escritos denigratorios le libran de la venganza partidista ${ }^{108}$. Pero

105 Amengual i Batle: Llengua $i$ catecisme, p. 111, nota 7 donde se apunta que existe un cambio de mentalidad, que origina un vocabulario correspondiente.

106 Ver algunas referencias en FERRER FLÓREZ, Miguel: «Las críticas al obispo Bernardo Nadal Crespí», en BSAL, (Mallorca) 49 (1993) 378.

107 Diario de Mallorca, $\mathrm{n}^{\circ} .201,07-09-1814$, p. 1030, en FERRER FLóREZ, «Las críticas», p. 378.

108 BOVER ya dio suficientes indicios sobre las controvertidas opiniones expresadas con ocasión de la muerte de Nadal. Era el momento que se les brindaba a los que no compartieron sus ideas aperturistas. Pueden verse nuevas piezas de archivo en FERRER FLórEZ, «Las críticas», pp. 378 -386. 
unos y otros dejan entrever que Nadal, muerto al cabo de cuatro años de represión fernandina, está más cercano a la libertad que se abrirá paso, que al «adorado Fernando VII» y al «mejor de los Monarcas» ${ }^{109}$, al cual cortésmente había aludido.

Su obra pastoral, plasmada en la multiplicación de los centros de atención ministerial, con la creación de las vicarías in capite, el haber sido el primer obispo postridentino que publicó un catecismo diocesano y las reformas interiores a la vida del obispado, ha tenido un alcance históricamente rastreable hasta nuestros días.

\section{El Canónigo Tesorero afrancesado y procesado}

Sucedió a Nadal en la oficina de traducciones otro mallorquín, el erudito y «el principal si no el único de nuestros afrancesados» ${ }^{110}$, Cristòfor Cladera $\mathrm{i}$ Company (1759-1816). Su formación inicial la debe a los capuchinos de Mallorca, representantes de la preilustración moderada, que le encaminaron hacia el «Colegio Seminario Conciliar de San Fulgencio» de Murcia ${ }^{111}$, para que descubriera nuevos horizontes. Mostró simpatías por la independencia de los Estados Unidos de América del Norte ${ }^{12}$. Estuvo atento a las novedades de la prensa extranjera, especialmente durante su estancia en Cádiz (1776-1785). A este puerto controlado por una aristocracia mercantil llegaban periódicos de toda procedencia. Lo que conoció Cladera en Cádiz le creó una adicción a las nuevas ideas, que logró difundir desde Madrid, donde por espacio de tres años y medio publicó con periodicidad quincenal el periódico Espíritu de los mejores diarios literarios que se publican en Europa (Madrid, 1787-1791) ${ }^{113}$. Richard Herr le considera como uno

109 Ibid.

110 OLIVER, Mallorca durante la primera revolución, p. 233.

111 Sureda Blanes, Josep: Mallorquins d'abir, Mallorca, Editorial Moll. Les Illes d'Or, 110, 1974, pp. 58 y Petites històries, Mallorca, Consell Insular de Mallorca - Editorial Moll. Biblioteca Bàsica de Mallorca, 12, 1987, p. 38. PoNs, Antoni: Dietari del Dr. Fiol. Memories de Don Joaquim Fiol, de Mallorca, Doctor en Drets, que comprenen de l'any 1782 fins en 1788, I, Ciutat de Mallorca, Publicacions de la Societat Arqueologica Luliana, MCMXXXIII, p. 119, en la cual Fiol nos informa que la Junta de la Universidad, el 1 de septiembre de 1783 conoció la Real Orden para que pudieran ser incorporados «els graduats en el col-legi de Murcia».

112 SUREDA BLANeS: Mallorquins d'abir, pp. 62-65 y Petites històries, pp. 47-48.

113 BOVER: I, $\mathrm{n}^{\circ} .279$, II, p. 193. El comentario que hace el autor, al final: «Esta obra contiene escelentes noticias, muchas de ellas relativas al concilio de Trento», está desplazado. Toca seguir a la obra siguiente, sobre los concilios, que mencionamos a continuación. Teniendo esto en cuenta, la observación de Bover es pertinente. En una instancia a Carlos IV, del 13 de enero de 1799, Cladera habla de esta obra suya, cf. José Simón DíAZ «El helenismo de Quevedo y varias cuestiones más», en Revista de Bibliografía Nacional, (CSIC) 6 (1945) 113. Cf. FuRIÓ, Antonio: «Advertencia del editor», en CladerA, Cristóbal: El Juicio Final. Poema en tres cantos escrito en ingles por Eduardo Young y traducido al castellano por, Palma, Por D. Felipe Guasp, Impresor Real, ${ }^{2} 1834$. Cf. VALERA HeRviAs, Eulo- 
de los cinco miembros más influyentes de la Sociedad Económica de Amigos del País de Madrid. ${ }^{114}$

No será superfluo observar que, siendo notoria su trayectoria como ilustrado moderado o cristiano, ${ }^{115}$ en tiempos del obispo Pedro Rubio, el año 1792, el hombre maduro que era Cladera fuera tonsurado y ordenado de las Órdenes Menores, entonces existentes, con lo cual entró en el clero, aunque nunca fuera ordenado de diácono o presbítero. Con aquel requisito pudo ser admitido por el Cabildo de la Catedral de Mallorca a la dignidad de Tesorero de la misma institución. Este hecho, anterior en dos años a la designación de Nadal como obispo de Mallorca, permite que adaptemos nuestra visión de las instituciones eclesiásticas mallorquinas, de modo que podamos descubrir en su seno una apertura ideológica mucho mayor de la que se puede percibir a través del prisma que sirve a la historiografía que presenta una Mallorca cerril e inclinada totalmente a la reacción.

Cladera asumió la representación de Mallorca en las Cortes de Bayona de 1808 , donde planteó la reforma de las órdenes religiosas ${ }^{116}$. No queda del todo dilucidado si en verdad, como recordaba fray Lluís de Vilafranca, Cladera asumió el cargo de Secretario de Estado y Ministro de Interior de José Bonaparte. 117 Posteriormente formó parte de la comisión que recogió la colección de obras de arte que su rey quiso entregar a su hermano Napoleón. Cladera impidió la salida de este tesoro artístico ${ }^{118}$.

Para nuestro objeto interesa observar que tradujo del francés Los Sacrosantos Concilios generales y particulares desde el primero celebrado por los apóstoles en Jerusalen, basta el Tridentino según el orden cronológico de su celebración y el análisis del padre Carlos Richard, del Orden de Predicadores...: con todas sus actas, canones, decretos y disertaciones sobre los principales puntos de dogma, disciplina, liturgia y costumbres de la

gio: Espíritu de los mejores diarios literarios que se publican en Europa, Madrid, 1787-1791, Madrid, Hemeroteca Municipal de Madrid. Sección de Historia de la Prensa (Fascículo 4) 1966 y ABELLÁN, José Luis: Historia crítica del pensamiento español, Tomo III: Del Barroco a la Ilustración (Siglos XVII y XVIII) Madrid, Espasa-Calpe, S. A., 1981, pp. 760-762.

114 Ver, también, SERVER I ROTGER, Pau Joan: «Defensa del descobriment americà per un mallorquí il·lustre del segle XVIII: Cristòfol Cladera Company (1760-1816) (Tresorer de la Seu de Mallorca) en Congrés Internacional d'Estudis Històrics (1992. Palma) II, Palma, Institut d'Estudis Baleàrics, 1992, pp. 193-200. Cristôfol Cladera Company, (Amèrica l'altra història de les Balears. Col-lecció de Balears i Amèrica, 16) (Comissió de les Illes Balears per a la commemoració del $\mathrm{V}^{\grave{e}}$ Centenari del descobriment d'Amèrica) dip. leg. 1992. (Se añaden algunos grabados al texto anterior, que va traducido al castellano y al inglés.

115 SERVER I ROTGER: Cristòfol Cladera Company, p. 7.

116 Cf. MERCADER RIBA, J. José Bonaparte rey de España 1808-1813. Historia externa del reinado, Madrid, 1971, pp. 38-40.

117 Nuestra opinión se inclinaría a açeptar que se trata de un hecho. Véase SERVER I ROTGER: Cristôfol Cladera Company, pp. 12-13, donde cita autores contemporáneos de Cladera. No obstante otros historiadores no lo creen real. Tendremos que aguardar estudios más precisos.

118 VALERA HERVIAS: Espíritu, pp. 20-21. 
Iglesia desde Jesu-Christo..., traducidos... por Don G. C....119. Cladera, declarado admirador del pensamiento innovador, tradujo la obra de un antirrevolucionario. Según declara en la introducción, pretende oponerse «á los progresos de la Ilustración mal entendida» que confunde Dios con la naturaleza ${ }^{120}$. Añade que el estudio de los concilios reformaría por sí mismo la Teología «de puros conceptos imaginarios, que se enseña en perjuicio de la verdadera y santa que es la única, necesaria y útil»»121.

Con esto quiere contribuir a que los cristianos sigan a los Apóstoles y «huyan de las perversas novedades»122.

Para todo ello pone en manos de los diversos ministros y de los mismos fieles estos instrumentos de reforma. El obispo, el confesor, el predicador, serán modelos y aprenderán de los concilios la verdadera historia de la Iglesia ${ }^{123}$.

Señala algunas novedades con respecto a la obra de Richard, que traduce. Quiere resumir las noticias auténticas sobre todos los concilios, concediendo preferencia a las histórico-dogmáticas ${ }^{124}$, para evitar referencias simplemente disciplinares, dada su caducidad. Otra novedad se refiere al vacío que va a llenar en la bibliografía española, con un tratado completo sobre todos los Concilios en general ${ }^{125}$. Esta última promesa se cumple en el mismo primer tomo, dedicándole más de 160 páginas. Notemos que, en las seis páginas de la introducción y presentación de la obra, no podemos inventariar una sola mención del papa y de sus funciones. El planteamiento de Cladera no lo exige. No obs-

119 Madrid. Por Don Antonio Espinosa, 11 volúmenes, en 4t, 1793-1796. El dominico y gran apologista y adversario de los ilustrados y jansenistas, y asesinado por el ejército francès invasor, en Bélgica, después de haber dejado Francia, Charles-Louis Richard, (1711-1794) autor de l'Analyse des conciles généraux et particuliers, I-IV, Paris 1772-1773. He de agradecer al Sr. Joan Alemany su colaboración para localizar esta obra. BOVER: I, 279, III, p. 193 y PALAU, A., Manual del librero bispanoamericano, 3, Barcelona - Madrid 1960, $\mathrm{n}^{\circ} .55039$, p. 502; Id.: XVIII, Barcelona 1966, $\mathrm{n}^{\circ}$. 284.167, de la misma forma que en el Indice alfabético de títulos -Materias, correcciones, conexiones y adiciones, Empúries - Oxford, 1982, p. 84, nº 55.039, atribuyen la traducción de esta obra a Cladera; pero no deja de ser intrigante que los tomos impresos se presenten bajo el nombre de «Don $G$. C.», que no se corresponden con las iniciales de Cladera. Sin embargo él mismo se presenta como su autor en una instancia que dirigió Carlos IV, el 13 de enero de 1799, manifestando que no pudo dirigirse a Roma, «por no tener concluida la publicación de su obra Los Sacrosantos Concilios generales y particulares». Texto que dio a conocer DíAZ, José Simón: «El helenismo de Quevedo y varias cuestiones más», en Revista de Bibliografía Nacional, (Madrid) 6 (1945) 113. Véase, también, Antoni Furió, en la edición del Juicio final, mencionada, p. (XVI) $n^{\circ}$. 3. Con todo, hemos de sorprendernos al comprobar que las ideas del autor, Richard, eran bien diversas de las de Cladera. El prólogo que éste redacto para el volumen primero es muy ambiguo. Véase, también lo que anotamos en Història de l'Església a Mallorca, pp. 154-155.

120 Sacrosantos Concilios, I, p. [1]. Damos así la paginación, puesto que la Introducción no la lleva.

121 Ibid. p. [5].

122 Ibid. p. [2].

123 Ibid. p. [2].

124 Ibid. p. [3]

125 Ibid. p. [3].

Hispania, LXII/3, núm. 212 (2002) 907-956 
tante, es llamativo. El resumen histórico sobre los concilios se enfrenta con una cuestión que, en el Vaticano I (1869-1870) será objeto de debate, la confirmación papal de los concilios.

Desconocemos cuál fue la tirada de esta obra. Pero es fácil comprobar que no es conocida y que hasta los historiadores de la Iglesia de nuestros días suelen ignorarla por completo. Con todo, siendo un caso tan raro en la literatura española, parece que no debería pasarse tan fácilmente por alto.

Como contrapunto a la vuelta a la disciplina antigua, en Mallorca, ya entrado el s. XIX, se editó una obra antijansenista, cuyo significativo título suena así: Palinodia de Febronio en la alocución del Sumo Pontifice Pio VI, de gloriosa memoria, al Concilio celebrado en 25 de diciembre de 1778 Ec. ${ }^{126}$

Cladera fue un espíritu inquieto y ansioso de gloria y triunfo. No podemos clasificarle entre las primeras figuras; pero su incansable carrera tras las novedades europeas y americanas le hizo un servidor de las ideas ilustradas en la monarquía hispánica de final del s. XVIII.

Este mallorquín que, después de investigar la historia de América y también la de las Baleares ${ }^{127}$, se enfrascó en un diccionario universal de física e intervino sobre cuestiones contemporáneas, corrió peor suerte que Nadal. El ambiente de represión, consiguiente a la vuelta de Fernando VII, acumuló las desgracias sobre Cladera. Por sus ideas y sus servicios a Napoleón fue desterrado. Ante sus numerosas instancias recibió el correspondiente indulto, solicitado, entre otras razones, porque estaba procesado por el tribunal eclesiástico, por desatender a su beneficio en la catedral. ¿Por qué se le procesó precisamente en medio de este ambiente hostil? Lo más probable es que la iniciativa viniera del exterior. Con todo, el cabildo le honró con vistosas exequias y con la acogida de sus restos en el espacio catedralicio. Era el año 1816. Nadal moriría dos años más tarde.

\section{La historiografía}

La tarea historiográfica y la hagiografía en Europa conoció grandes avances, siguiendo a los maurinos y a los bolandistas. En Mallorca estos resultados se hicieron esperar mucho.

${ }_{126}$ Palma, F. Guasp, 1814, $4^{\circ} ., 59$ pp. BOVER: II, Ap. 476, p.664.

127 Sobre los Apuntes para formar una bistoria crítica del Reino de Mallorca, BOVER: I, 279, p.195, XIII, Jovellanos escribió a Mn. Josep Barberí: «En quanto a Cladera si su dictamen de Vm. no es absoluto y decisivo, ya verá lo que le viene encima. Si pues empezó a pedir se le empezare a dar, con nada se contentará: hará sudar a otros aquí, y entretanto se paseará para lucir despues a cosa suya [...] Es menester que sepa que la historia de Mallorca no se puede escribir sino en Mallorca: que aun aquí nadie la puede escribir, sin que se le franqueen todos los archivos [...] Debe saber que en Dameto y Mut nada falta, (salvo el estilo)», citado por GuASP POU, «El Dr. D. José Barberi» (Continuación) III, en BSAL (Mallorca) 21 (1926-1927) 138-139. Todavía hoy, ante archivos importantes infranqueables, podemos repetir los lamentos de Jovellanos. 
En cuanto a la hagiografía, como botón de muestra, hemos de decir que los obispos de Mallorca iban remitiendo a Roma el listado de las reliquias guardadas en la catedral, sin que la crítica más elemental tuviera incidencia. Ni siquiera se aplicaron los criterios adoptados para depurar las noticias sobre los milagros atribuidos a la Mare de Déu de Lluc, y a la de la Salut ${ }^{128}$, de Palma. Creemos que se trata de un fenómeno muy generalizado éste de establecer un vado entre lo que se llama devoción popular y los resultados de la ciencia histórica.

A decir verdad, hemos de llegar a la segunda mitad del s. XX para que la historiografía de Mallorca tenga carta de naturaleza en la Universidad. Esto no obstante, sus cultivadores extrauniversitarios de antaño siguen prestando muy buenos servicios y los hay que siguen siendo imprescindibles. Nuestro objetivo, ahora, se limita a intentar una aproximación, no más, a los que ya Oliver consideró como los que, antes de los vendavales de las revoluciones,

fundaron la bibliografía literaria y científica de Mallorca y, en suma, legaron á este país un inventario total de su pasado y de su presente, de sus hombres notables, de su literatura y de su arte, ensayando aquí la erudición reflexiva y metódica que instauraban en el continente Sempere y Guarinos, Mayans, Florez, Lampillas y demás escritores del mismo fuste ${ }^{129}$.

Los representantes más cualificados, citados por Oliver ${ }^{130}$, son el cronista y correspondiente de la Academia de la Historia, Jeroni Alemany (1693-1753) el analista y paborde Guillem Terrassa (1709-1778) ${ }^{131}$ Bonaventura Serra, ya mencionado y el capuchino, Lluís de Vilafranca, a quien aludiremos en breve. No creemos que haya motivos probados para que incluyamos entre los preilustrados a los dos primeros. En todo caso, podemos detenernos en los otros, que en las islas introdujeron la aplicación de la crítica histórica y literaria, aunque con bastante retraso respecto a lo que acontecía en la Península Ibérica.

Para estudiar esta línea científica, Trias Mercant ha subrayado dos versiones en la interpretación de la cultura española, que luego aplica a la mallorquina. La primera depende del benedictino P. Feijoo, que atribuiría el atraso cultural de España en especial al descuido de las ciencias naturales. En cambio, la otra versión, sería la del alicantino, jesuita extrañado, Francesc Xavier Lampi-

128 Rafel BusQueTs publicó el Llibre de I'Invenció i Miracles de la Prodigiosa Figura de Nostra Senyora de Lluch, [Mallorca] 1684. El autor se sirve de un proceso canónico realizado para esclarecer lo histórico de lo legendario. Los criterios de historicidad eran mucho más laxos de lo que pensaríamos hoy. JORDI, Joan Baptista: en el Libre en que van apuntats alguns dels miracles que ha obrat Nostra Sra. de la Salud venerada en la parroquia de Sant Miquel, comensat el dia 21 de novembre de 1645, no hace comentario alguno digno de mención.

129 OLIVER: Mallorca durante la primera revolución, p. 28.

130 Ibid.: p. 27.

131 FONT OBRADOR: Historia de Llucmajor, V: El siglo XVIII, pp. 593-597. 
lles, el cual reivindica la cultura española de las acusaciones de decadencia, que se formulaban sobre todo en Italia, lugar de su exilio ${ }^{132}$.

Inspirándose Trias Mercant en Oliver señala a Serra cómo un representante de la valoración del P. Feijoo, y le atribuye un planteamiento que llama "panmallorquinismo» ${ }^{133}$. Este término puede llevar a un malentendido, atribuible a una mentalidad isleña, como si se tratara de mallorquinizar el mundo, cuando lo que pretende señalar Oliver es el carácter enciclopédico de la curiosidad de Serra, que no deja campo del interior de la isla fuera de su interés. Serra no se limita, como los demás autores, a la literatura, historia, etc., sino que, como ya hemos dicho en su lugar, se adentra en la experimentación científica del más diverso carácter. De ahí su apego a Feijoo ${ }^{134}$. Nuestro enfoque nos ha llevado a tratar de Serra con anterioridad, desde la perspectiva de sus contactos con los ilustrados franceses y peninsulares, por lo que dejamos de lado su aportación historiográfica, muy apreciable, por otra parte, y pasamos a realizar una cata en un autor poco conocido y menos estudiado, que es el mejor exponente de la línea que encuentra en Lampilles su figura emblemática. Nos referimos a Mn. Antoni Roig.

\section{Un émulo de los jesuitas expulsados, a escala insular: Mn. Roig}

Antes de hablar de Roig, deberíamos dedicar un apartado a un jesuita mallorquín, Ramon Diosdado Caballero (Palma (Mallorca) 1740- Roma 1830) ${ }^{135}$. Con todo seremos muy breves, puesto que este expulsado, en realidad, tuvo poca relación con Mallorca y no se ocupó de su historia. Estuvo relacionado con sus hermanos de religión, el mallorquín Bartomeu Pou, el catalán Masdéu y el alicantino Lampilles. Sus estudios sobre la producción literaria de los miembros de la Compañía de Jesús son rigurosos ${ }^{136}$. Estuvo preocupado por las relaciones hispanoamericanas y por la historia del Nuevo continente. Sus intereses historiográficos no incidieron en los autores isleños que, en cambio, pudieron aprovechar la ingente labor de otros jesuitas expulsados.

132 Truas Mercant: Història del pensament, [I] p. 260. Puede verse BAtLLORI: Els catalans en la cultura bispanoitaliana, pp. 23-26,64,190; Id. Història, classicisme i filosofia al segle XVIII: Gustà, Pou i els Masdéu, pp. 177-178; 303-304;332-333.

133 OLIVER: Mallorca durante la primera revolución, p. 28 y TRIAS MERCANT: o. c., p. 261.

134 Véase el fragmento de su obra inédita, Historia de Mallorca, que se guarda en la Biblioteca del Monestir de La Real, Mallorca, que citamos en «Nova documentació», pp. 192-194, donde leemos reflexiones, sobre la lengua catalana, semejantes a las que apreciaremos en Antoni Roig. En TRIAS MERCANT, o. c., p. 261, hay alusiones a la historia.

135 BOVER: I, nº. 358, pp. 245-247; BATLLOR, Miquel: «Jesuites mallorquins a Itàlia», a Els catalans en la cultura bispanoitaliana, Obra completa vol. X. Edició a cura de DURAN, Eulalia, (dir.) i SOLER ViCENS, Josep, (coord.). Pròleg de BENíteZ I RierA, Josep M.; (nº. 27) València 1998, pp. 261-277.

136 Bibliotheca scriptorum Societatis Jesu. Supplementa. (apud Franciscum Bourlie) Romae 1814-1816. 
Si bien por nacimiento y largo ministerio Mn. Antoni Roig i Rexach (Ferreries, Menorca, 1750 - Palma, Mallorca, 1808) fue menorquín, con todo, hemos de empezar esta sección dedicándole una mención muy especial. En efecto, se formó en el colegio de Monti-sion de Palma, antigua institución docente que por pocos años mantendrían aún los jesuitas. Prosiguió su carrera en la Universidad Literaria de Mallorca, en Palma. Aquí se doctoró en filosofía el 11 de abril de 1767. Lo más probable es que cursara la teología en el mismo centro. Con todo, la graduación doctoral la recibió en Aviñón, lo cual no equivale a decir que cursara en esta antigua sède de los papas.

Como ha demostrado Vicent de Melchor, fueron muchos los menorquines contemporáneos que, después de una debida preparación, se trasladaron por un corto espacio de tiempo a Aviñón, para rendir los exámenes correspondientes a las respectivas especialidades. Tal sería también el caso de Mn. Roig. En cuestión de cuatro días superó las pruebas del doctorado en teología, el 26 de mayo de 1770 y las del mismo grado en derecho civil y canónico el día 29 del mismo mes $^{137}$.

La proximidad de ambas fechas nos inducen a aplicar a Roig los argumentos que da de Melchor, para excluir largas estancias en Francia, por razón de estudios, de otros menorquines, graduados en universidades galas. Roig habría viajado a Aviñón, ciudad todavía bajo dominio papal, sólo para examinarse en las facultades mencionadas, después de cursar en Palma. Nada de extraordinario tiene semejante proceder. Paralelos los hallamos en sentido inverso. Un buen número de catalanes obtuvieron sus títulos en Mallorca, como hemos recogido más arriba. Debo corregir, por tanto, todo lo que en un ensayo biográfico de nuestro personaje consideré como fruto de una larga estancia, en la ciudad del condado papal de Venaissin ${ }^{138}$. En efecto, no sería hasta los tiempos de la Revolución Francesa, cuando este territorio pasaría al estado francés.

La primera obra que le acredita para que le adscribamos a los preilustrados es su edición de la Circular de Severo de Menorca (año 418) publicada en Palma, el año 1787. Tanto su introducción como las notas históricas son un modelo de rigor, a la par que mejora textualmente la edición de Baronio ${ }^{139}$, aun-

\footnotetext{
137 DE MELCHOR, Vicent, «El pas del jove Joan Ramis per la Universitat d'Avinyó (1767): una aportació de la cultura a la Menorca del segle XVIII", en Joan Ramis i Josep M. Quadrado: de la Il-lustració al romanticisme. A cura de Maria PAREDES i de Josefina SAlORD. (Universitat de les Illes Balears. Departament de Filologia Catalana i Lingüística general - Institut Menorquí d'Estudis) Publicacions de l'Abadia de Montserrat 1999, pp. 257-280. El nombre de Roig aparece citado en la p. 275, Apèndix I, como doctorado en ambos derechos.

138 Amengual i Batle: Antoni Roig $i$ Rexart, pp. 26-27,34 y 57.

139 El título, muy rebuscado, es como sigue: Antonii Rogii Magonensis de Sacris apud minorem balearem antistibus Severo potissimum deque istius epistola exercitatio et in eamdem epistolam animadversiones. Palmae Balearium, Anno MDCCLXXXVII. Excudebat Antonius Miralles Pro-Typograph[us] Reg[ius]. IX $+247+1$ de corrección de erratas. Sobre esta edición, cf. Amengual i Batle, Antoni Roig $i$ Rexart, 51-53. Véase también lo que decimos sobre el valor del texto que adoptó RoIG en Origens del Cristianisme a les Balears $i$ el seu desenvolupament fins a lèpoca musulmana, Mallorca, Editorial
} 
que Migne, en el s. XIX, la ignorara en. su gran programa de reediciones de la patrística. No podemos extendernos en la descripción de sus valores. Cuando inmediatamente presentemos la obra apologética de Roig, indirectamente hablaremos de ellos. Baste decir ahora que Roig era un conocedor de la historia, en sus representantes más críticos, como los maurinos y los bolandistas, Muratori y otros eruditos italianos, y que estaba al corriente de sus métodos de crítica histórica y literaria.

Nos detenemos algo más en su obra anónima, Reflexiones crítico-apologéticas sobre algunos escritos relativos a la isla de Menorca ${ }^{140}$. Ya su misma portada delata un espíritu en sintonía con su tiempo. Los breves ensayos vindicativos de Menorca, su historia y geografía, su pueblo culto, bien merecen el nombre de reflexiones. Y su autor se limitaba a decir de sí mismo que: Hacialas un amigo del País. Anteriormente había redactado un Resumen histórico de Menorca escrito en 1785 por encargo de la R. Academia de la Historia ${ }^{141}$. Lo publicó Gabriel Llabrés i Quintana cuando era responsable de la Revista de Menorca, en $1896^{142}$; pero no sabemos de dónde tomó el texto, si de alguna versión existente en Menorca, o en Mallorca, donde murió Roig, o de la Real Academia de la Historia. En cambio hace un decenio que se publicó el manuscrito existente en ella desde 1787, obra de Joan Ramis i Ramis ${ }^{143}$. Con este texto de Ramis i Ramis confundió Gabriel Llabrés i Quintana el informe de Roig, cuando atribuye una referencia al mismo a Jaime de Villanueva, el cual, en realidad habla expresamente del texto de Ramis i Ramis, con el título un tanto modificado. Por lo cual, creemos que Villanueva no conoció la obrita de Roig ${ }^{144}$. De hecho, este escrito ha permane-

Moll. Els Treballs i els Dies 36 i 37, 1991, I, p. 60, con la nota 6 y II (1992) p. 11; FANER I BAGUR, J. Bosco: Humà en l'autoritat. Antoni Roig $i$ les seves cartes d'ofici, (Monografies Ferreienques, 7, Ferreries (Menorca) 1991, pp. 13-14.

${ }^{140}$ El título completo es como sigue: Reflexiones crítico-apologéticas sobre algunos escritos relativos a la Isla de Menorca y a sus naturales. Hacialas un amigo del País. Barcelona, Por Francisco Suria y Burgada, Impresor de S. M. Sin indicación de fecha, 140 pp., + 2 de índices +1 de fe de erratas, en $8^{\circ}$. La escribió contra el historiador inglés John Amstrong. Cita autores franceses, como el conde de Bussy Rabutin, el marqués de Valmont, véase además, sobre literatura francesa, la p. 59 . Véase la nota copiosa de BOVER: II, $\mathrm{n}^{\circ}$. 1075, pp. 287-290.

141 VIVES, Sebastián: Episcopologio de la Santa Iglesia de Menorca, Ciudadela, Imp. y Lib. Del Sagrado Corazón de Jesús, 1903, p. 5, nota 1. Parece que el autor seguía este escrito, aunque no da referencia alguna sobre su publicación, hecha por LLABRÉs, como indicamos en la nota siguiente.

142 Revista de Menorca (Maó) (1896-1897) pp. 12-22. Véase en la nota (*) de la p. 18, la firma abreviada como «Ll» es de Gabriel Llabrés i Quintana, tan vinculado a la «Societat Arqueològica Lul-liana" y a su boletín, así como al estudio de diversos archivos.

143 RAMIS I RAMIS, Juan: Resumen topográfico e bistórico de Menorca. Manuscrito de 1787. Con estudio preliminar de José Gella ITURRIAGA. Madrid, Real Academia de la Historia, 1989. Se pueden observar muchas apreciaciones semejantes a las de las Reflexiones de Roig. El manuscrito, deteriorado sólo en su cubierta, está pulcramente escrito, en papel azul muy claro. Véase un apunte sobre Ramis, obra de SALORD RIPOLL, Josefina: «Apologia il-lustrada del llibre. Lectures i modernitat cultural al món de Joan Ramis», Revista de Menorca (Maó) (1996) 19-28.

${ }^{144}$ Viage Literario à las Iglesias de España: XXI: Viage à Mallorca, I, Madrid 1851, p. 3. 
cido casi ignorado ${ }^{145}$. Cabe preguntarse, ¿̇por qué la Real Academia de la Historia pidió un segundo informe, esta vez a Ramis i Ramis? Posiblemente porque el de Roig había resultado demasiado escueto, aunque muy ajustado a la verdad histórica. Comparado con el de su amigo, es muy lacónico y poco detallado.

Roig no sólo se presentó genéricamente como amigo de su tierra, sino que en sus palabras había una declaración de su condición de socio de número de la SEMAP. Además, es uno de los que tuvo necesidad de intercambiar correspondencia en latín con Bonaventura Serra, Josep de Pueyo i Pueyo ${ }^{146}$, el cardenal Antoni Despuig i Dameto, etc. Aunque conoce numerosos autores franceses, civiles y eclesiásticos, ya hemos indicado que este bagaje cultural no depende de su corta estancia en Francia. Pudo gozar de la oportunidad de adentrarse en conocer alguna buena biblioteca aviñonesa, pero poco más. No hemos de excluir que conociera directamente alguna comunidad de las Hijas de la Caridad, fundadas por S. Vicente de Paúl. Pero su aproximación al gran maestro S. Francisco de Sales ${ }^{147}$, no puede venirle de sus días aviñoneses.

Con estos antecedentes, hemos de atribuir más protagonismo a Roig en su labor para favorecer la felicidad de sus feligreses. En efecto, él es el sembrador de la primera casa de caridad. En esta plantación, en el s. XIX, se inspiró una parte notable de la vida religiosa apostólica femenina en Mallorca.

Por otra parte, es amigo de los eruditos menorquines y está actualizado en el manejo de la producción mallorquina, en especial de la que sale del estudio del mencionado Serra.

La dominación francesa, que comenzó el mismo año en que nació Roig, pudo aportar una cierta influencia cultural, un cultivo del francés, etc., en Menorca. Pero tuvo su final en 1763 , cuando nuestro personaje entraba en la adolescencia. Por esto, la cultura de Roig sólo indirectamente depende de sus contactos con lo francés. Teniendo esto presente, hemos de esperar que se abran más luces en el panorama cultural balear, para poder deslindar los cauces por los cuales se transmitían las nuevas corrientes históricas. Posiblemente la universidad no fuera de tan baja calidad como se ha supuesto. Por otra parte, Roig afirma que las buenas bibliotecas se daban en Menorca.

Sentado lo anterior, paramos mientes en su escrito apologético, porque es el que mejor revela su conocimiento de la época. Conviene, ante todo que situemos esta obra, en la cual critica la superficialidad y desconocimiento de cua-

145 Es muy extraño que RAMIS I RAMIS, Juan: Varones ilustres de Menorca y noticia de los apellidos que más se ban distinguido en ella, Mahón, 1917, ps. 195-198, ni BOVER mencionen esta escrito de Roig.

146 ROURA I AULINAS: L'Antic Règim a Mallorca, pp. 48-49, nota 140, alude a la raigambre aragonesa de los Pueyo y cita a Javier GIL Pujol, «La proyección extrarregional de la clase dirigente aragonesa en el siglo XVIII", en MOLAS, P., y colaboradores, Historia social de la Administración Española. Estudios sobre los siglos XVII y XVII, Barcelona 1980.

147 LAMARCA LANGA: La cultura del libro, pp. 56, 65-66. Se trata del autor de espiritualidad no español más representado en las bibliotecas valencianas.

Hispania, LXII/3, núm. 212 (2002) 907-956 
tro autores, que publicaron sus historias o simplemente sus impresiones sobre Menorca $^{148}$.

Roig estudió varias obras en francés y alguna en castellano, en las cuales halló inexactitudes y errores. La Inquisición impidió que entablara una confrontación con el ingeniero inglés, John Armstrong, el cual, después de vivir diez años en Menorca, escribió una Historia natural y civil de la Isla de Menorca, que se reeditó en su original inglés. Roig menciona su traducción al francés, publicada el $1770^{149} \mathrm{y}$ en las bibliotecas se hallan ediciones en castellano, que pertenecen a diversas épocas, comprendida la nuestra. El mapa de Menorca que levantó el mencionado científico, es de mucho valor. Pese a los desacuerdos, se consideró el escrito del inglés como una obra "de bastante mérito»" ${ }^{150}$. Roig se lamentó de que no conociera los autores clásicos, la Circular de Severo, la presencia de los vándalos, la conquista catalana del s. XIII, etc. Añade que desconoce la flora, los fósiles e insectos de la isla. Roig llenará bastantes lagunas del historiador enviado por el poder que había invadido la isla, con ocasión de la guerra de sucesión. La respuesta a los demás productores de libros de viajes, o de ciencia histórica acerca de su patria, le brinda ocasiones de frecuente rectificación.

La obra se publicó en Barcelona, anónima y sin datar. El ejemplar que conocemos, inmediatamente después de la indicación de que las meditaciones proceden de un amigo del país, con caligrafía bien nítida, añade: Por el Dr. D. Antonio Roig. Bover, cuyo padre tuvo por condiscípulo a Roig, en el colegio de los jesuitas de Monti-Sion de Palma, se las atribuye igualmente y no hay especiales motivos que nos hagan dudar de su autoría. Roig explica sus reparos para dar a luz esta obra con su nombre. Aunque su producción se editó en Maó y Palma, publicó estas reflexiones en Barcelona. No fue la única obra suya editada en la capital catalana. En este mismo lugar la imprenta sacó su panegírico sobre el erudito teatino san Giuseppe Maria Tommasi (1649-1713) entonces beatificado.

Creemos que las Reflexiones son el último de los estudios que publicó Roig. Su edición es posterior al año 1789 , porque cita un edicto de la Inquisición, fechado el 10 de mayo de este año. Además, contesta al predicador que pronunció el panegírico, con ocasión del nacimiento de los infantes Carlos y Felipe, lo cual ocurrió en 1788. Ha de ser muy posterior a su nombramiento como párroco de $\mathrm{Fe}-$ lanitx (Mallorca) puesto que Roig pasó a esta isla con posterioridad al 13 de agosto de 1790. La época que mencionamos, ocupada en la preparación de oposiciones a curatos, no era propicia para enfrascarse en temas eruditos.

Con todo, cuando cita unos versos, confiesa que cuando entró en aquel lugar apenas tenía barba, en cambio, al momento de redactar estas reflexiones la

\footnotetext{
148 Reflexiones, p. [5]. Damos así la paginación que asignamos al prólogo, puesto que no la tiene.

149 «Resumen histórico de Menorca escrito en 1785 por encargo de la R. Academia de la Historia», en Revista de Menorca (Maó) (1896-1897) 13.

150 Reflexiones, en la introducción y al inicio de la nota (a) pp. [9-13] donde ocupa todas las páginas casi por entero.
} 
tenía «crecida y cana»151. Esta alusión cuadra muy bien con la su etapa de Ferreries, empezada antes de cumplir los 25 años. En cambio, lo que escribe poco antes: «Habito en un lugar donde es más fácil hablar con los montes, que con hombres cultos», ${ }^{152}$ puede referirse tanto a Ferreries como a Felanitx. El lamento que expresa por la falta de personas cultivadas debe ser una concesión literaria, puesto que al mismo Roig le veremos hablar de la cultura del clero menorquín, de las bibliotecas, etc. El clero de Mallorca debía estar en unas condiciones semejantes. Más allá de los clérigos y algún que otro profesional, pocos debían ser los. individuos apasionados por las letras y ciencias, en Ferreries y en Felanitx. De todas formas, de los tres presbíteros con que contaba Ferreries, dos eran doctores ${ }^{153}$. Ha habido quien afirmó que la edición de esta obra corresponde al año 1795, cuando su autor llevaba ya cinco años de párroco en Felanitx ${ }^{154}$.

Comprobamos que Roig conoce y cita a los jesuitas exclaustrados, de origen catalán y valenciano, establecidos, por la violencia del despotismo reinante, en Italia. Eran autores de grandes obras vidicativas de la aportación española a la literatura. Su talante a veces se vuelca en la propensión a la apología; pero en muchos campos fueron innovadores e introductores en el mundo hispánico de nuevas formas de afrontar la ciencia histórico-literaria.

Roig también consideró su tierra y su cultura indebidamente tratadas. Y en aquellos extrañados de su país encontró la inspiración. Desde el mismo título de su obrita, hasta en su mismo contenido, hay un reflejo de aquella gigantesca obra realizada en el extranjero.

Para construir su informe, en la parte que considera la historia de la antigüedad, recurre directamente a Diodoro de Sicilia, Estrabón, y Hesiquio, entre los griegos, y a Tito Livio, Cicerón y al recopilador Floro. Por supuesto, no duda en hacer valer su edición del texto latino de la Circular del Obispo Severo ${ }^{155}$.

Entre los escritores más recientes, menciona a Samuel Bochart (1599-1667) historiador y teólogo protestante, autor de estudios sobre los pueblos de la antigüedad ${ }^{156}$, a los PP. Feijoo, Josep Finestres (1688-1777) Joan Francesc Masdéu (1746-1817) ambos jesuitas, y a Gregori Maians i Ciscar (1699-1781) y

151 Ibid.: pp. [4-5].

152 Ibid.: p. [4].

153 FANER I BAGUR: Humà, p. 28.

154 Cf. Riudavets, Pere: Historia de la Isla de Menorca, 1888, citado según SALORD I RIPOLL: Antoni Roig, p. 137, nota 1.

155 En la introducción a De sacris, pp. 34-99, presenta las diversas opiniones sobre la autenticidad y valor histórico de la circular. En las pp. 42-44, después de citar un gran elogio de su obra, aduce un largo texto de DE TILLEMONT, Louis Sébastien Lenain: Memoires pour servir à l'bistoire ecclésiastique des six premiers siècles, al cual siguen dos pp. con un fragmento de Claude Fleury, «Scriptor nobilissimus».

${ }^{156}$ Citamos su Geographiae Sacrae pars prior: Pholeg seu de dispersiones gentium et terrarum divisione facta in aedificationem turris Babel; et pars altera: Chanaan seu de coloniis et sermone Pboenicum, Caen, 1646 y otras ediciones en el mismo lugar y en Frankfurt. 
hasta apela al Conde de Campomanes, Pedro Rodríguez (1723-1803) en temas históricos y, en la historia de la literatura, saca partido de su conocimiento de las obras de los jesuitas expulsados Joan Andrés i Morell (1740-1817)157, Francesc Xavier Lampilles (1731-1810) ${ }^{158}$, y de la obra monumental de los hermanos Rafael y Pedro Rodríguez Mohedano (ca. 1725-ca. 1800) ${ }^{159}$, ambos franciscanos. Para cantar las bellezas de su tierra, apela a lo que pudieran cantar poetas en latín, como los jesuitas Maciej Kazimierz Sarbiewski (1595-1640) polaco, y el francés René Rapin (1621-1687) en su Ruris delitiae, a Bartolomé Juan Leonardo de Argensola (1562-1631) ${ }^{160}$, etc. Conoce a Ludovico Antonio Muratori (1672-1750) y a otros historiadores críticos que le precedieron ${ }^{161}$.

Roig es consciente de lo que exige «el que se llama por excelencia el siglo de las luces» ${ }^{162}$. Se percata de cómo Menorca dispone de buenas bibliotecas en los conventos Estas comunidades cuentan con profesores hábiles en filosofía y teología, los cuales se adaptan al mismo método que se sigue en la Península. Este rigor académico ha originado que, en la visita pastoral de Pedro Rubio Benedicto, realizada en 1782 , hallara "un Clero muy ilustrado» ${ }^{163}$. Por otra parte, lamenta la carencia de

ciertas felices circunstancias que por explicarme con el historiador crítico de España ${ }^{164}$, dan vigor a los ingenios de una Nacion; pero hemos logrado una de aquellas proporciones que en expresión del mismo son capaces de causar grandes variaciones en la cultura ${ }^{165}$.

Roig aquí utiliza el término nación dándole una carga bastante semejante a la que ya por entonces llenaba de contenido esta palabra. Se vislumbra un sentido más moderno, que le aleja del mundo de la isla de Menorca, y le aproxima a una comunidad más vasta, que englobaría los países de la corona hispánica

157 Reflexiones, p. 44, refiriéndose a la traducción castellana de su obra, Historia de toda Literatura, L. I, De la poesía, Cap. 3. Parece que debería referirse a Del origen del progreso y del estado actual de la literatura, 1782-1798, originariamente escrita en italiano, como ya hemos señalado.

158 Saggio Storico Apologetico della Letteratura Spagnuola contro le pregiudicate opinioni di alcuni moderni, Genova, 1778-1781, en la introducción a De sacris. p. V, y en las Reflexiones, p. 65, nota (a) donde alude al autor por «su acostumbrada elegancia el invicto apologista de la literatura Española». Cf. OlIVER: Mallorca durante la primera revolución, p. 28.

159 Su gran obra no pasó del tomo décimo: Historia literaria de España: origen, progresos, decadencia y restauración de la literatura española.

${ }_{160}$ Cita el tomo segundo del Parnaso español.

161 En De sacris, pp. 7,12, 34 (Manuel Risco (1735-1801)) etc., cita a Enrique Flórez (1702-1773).

162 Reflexiones crítico-apologéticas, 66.

163 Ibid.: p. 70.

${ }^{164}$ Se refiere a Masdéu, a quien acaba de mencionar, en la p. 66. Véase, sobre este historiador, BATLLORI: Els catalans en la cultura bispanoitaliana, pp. 3-38; Id.: Història, classicisme i filosofia al segle XVIII: Gustà, Pou i els Masdéu, pp. 301-320.

165 Ibid.: pp. 66-67. 
aunque, como veremos más adelante, en un sermón de sabor patriótico, también se agarra al término nación, para expresar la grandeza de la victoria sobre los ingleses, cuando se rindió el Castell. Se trata de «un triunfo de la Nación» ${ }^{166}$. Aunque en algunos pasajes sigue identificando el reino como una cuasi propiedad del rey, en un encendido elogio de la paz ${ }^{167}$, cuando habla de la monarquía, suele tener como punto de mira el pueblo en general.

Un pasaje significativo en este sentido lo pronunció en el panegírico que conmemoraba la paz de Versalles, con la cual se liquidaba el contencioso menorquín con la Gran Bretaña. Sabe apreciar la paz como uno de los «medios mas conducentes para asegurar la felicidad del Estado» 168 .

En la paz el servicio de quienes manejaban las armas se transformará en otro tipo de prestación: «aumentando la poblacion, adelantando el comercio, fomentando la industria». Ésta será su eficaz contribución «al esplendor de la Monarquia, a la opulencia de la Monarquia, á toda suerte de prosperidades para la Monarquia» 169 . No extraña que, en esta línea, considere que el rey ha de ser solícito en procurar la utilidad de la población ${ }^{170}$.

Sale al paso de un viajero francés que, entre otras cosas, había escrito de los menorquines que «el idioma que hablan comunmente es el lemosino ó catalán ${ }^{171}$, algunos el castellano y el ingles». Roig apostilla: «y hubiera podido añadir que muchos se explican bien en frances, y otros en italiano» ${ }^{172}$. Roig refleja

\footnotetext{
166 Oración que en la Solemne fiesta celebrada en la Iglesia del Convento de Religiosas de la Purísima Concepción de Mabon. Dia 28. De Abril de 1782. En accion de gracias al Señor por la Rendición del Castillo de San Felipe. Pronunció D. Antonio Roig, Doctor en las facultades de Filosofia y Teologia, y Cánones, Cura de la Parroquial de Ferrerias y Vicario General de la Isla de Menorca. En Mallorca. En la Oficina de Don Ignacio Serrá, y Frau Impresor del Rey nuestro Señor, p. 32.

167 Resalta este aspecto SALORD I RIPOLL, Josefina: La fortalesa activa. Antoni Roig dins els seus sermons. Lliçó inaugural del curs 1989-90 al Seminari Diocesà de Menorca. Pròleg de Miquel ANGLADA GELABERT, Maó, Edicions Nura, 1989, pp. 14.17.

168 Oración que en la solemne fresta celebrada por el Ayuntamiento de Mabon en su Iglesia parroquial. Dia 15. de Febrero de 1784. En accion de gracias al Señor por el feliz alumbramiento de la Serenisima Princesa de Asturias, Nacimiento de los dos Infantes Don Carlos y Don Felipe, y ajuste definitivo de la Paz con la Nacion Britanica pronuncio D. Antonio Roig, Doctor en las Facultades de Filosofia, Teologia, y Cánones, Cura de Ferrarias y Vicario General de la Isla de Menorca. Juan Fabregues Impressor Real (Mahon) p. 22.

169 Ibid.: pp. 20-21. Citamos según SALORD I RIPOLL: La fortalesa activa, p. 17.

170 Ibid.: p. 22.

171 RAMIS I RAMIS: Resumen, p. 155, acaba sus disertaciones con esta referencia a la unidad de la lengua catalana: «La lengua menorquina es la misma, en sustancia, que la de Mallorca, Valencia y Cataluña; y no falta quien dice que en muchas partes no se habla con el gusto ni con el primor que en Menorca. A semejanza de otros idiomas, tiene sus bellezas, y defectos; y es de notar que, sin embrago de las variaciones de dominio que ha tenido Menorca durante este siglo, no se han introducido en la isla muchas expresiones ni voces tomadas de otras lenguas». Véase la impresión de un crítico anónimo, en "Intelligence and Remarks", publicado en North American Review and Critical Journal, Boston, 5 de mayo de 1817, pp. 128, 130-131, en DE MELCHOR, «El pas del jove Joan Ramis», pp. 276-277-278, especialmente las dos últimas pp.

172 Ibid.: p. 47.
}

Hispania, LXII/3, núm. 212 (2002) 907-956 
un momento en el cual la denominación de los idiomas no había caído aún en manos de ciertos políticos ${ }^{173}$. No sólo esto, sino que en el momento en que escribe, quedaban muy lejos la reales cédulas, en concreto la de Carlos III, de 1768 , en la cual reprimía el uso del catalán ${ }^{174}$. No sabemos qué grado de conocimiento tuvo Roig de esta política, porque los borbones españoles no habían imperado en Menorca. Por otra parte, en el campo de la reflexión científica, el mencionado Bonaventura Serra habló con la misma naturalidad ${ }^{175}$.

Sale en defensa de la cultura de muchas mujeres menorquinas, «que leen muy bien el lemosin y el castellano» ${ }^{176}$, y otras de Maó, Ciutadella y Villa Carlos «leen correctamente el frances». Y aunque no lleguen a la instrucción que proponen, entre otros, François Salignac de la Mothe Fenelon (1651-1715) la marquesa de Lambert ${ }^{177}$, y «la laboriosa Madama de Beaumont» ${ }^{178}$, saben más que muchas de las que, entre otras situaciones de privilegio, fueron educadas en medio «de lo que se llama ilustración» 179

Para calibrar el valor de los literatos menorquines, apela al jesuita exclaustrado Francesc Xavier Lampilles, y a la Historia Literaria de España, de los Mohedanos ${ }^{180}$, ambos historiadores de la literatura española.

Conoce a los Padres de la Iglesia. Cita no sólo a S. Juan Crisóstomo, S. Jerónimo, S. Agustín, sino también a autores menos conocidos, como Salviano de Marsella. Se sirve de Calmet, a quien ya hemos aludido entre sus autores conocidos, y en cuestiones dogmáticas se muestra conocedor de Sto. Tomás de Aquino. Para reforzar las actitudes cristianas, no duda en ampararse en $\mathrm{S}$. Francisco de Sales ${ }^{181}$.

Si sobrevolamos algunos de sus sermones publicados, observamos que están plagados de citas bíblicas y revelan, además, mucha erudición patrística. Con

${ }^{173}$ Que, desde el s. XIII, el catalán era la lengua común a Cataluña, Baleares y Valencia, lo recogía con normalidad el gran inspirador de Roig, cuyo nombre y obra citamos según la edición original, Giovanni ANDRÉs: Dellorigine, progressi e stato attuale d'ogni Letteratura, I, Parma 1782, pp. 283-285.

174 Cf. Llompart, Gabriel: «La real cédula de 1768 sobre la difusión del castellano y su repercusión en la diócesis de Mallorca», en BSAL (Mallorca) 33 (1965) 357-379, también su otra aportación «Una puntualización acerca de la enseñanza del castellano en Mallorca», en BSAL, 34 (1974) 404-406 y AMENGUAL i BATLE, Josep: «Nova documentació sobre la imposició del castellà a l'ensenyament del catecisme a la Seu de Mallorca, maig 1773-gener 1779», Fontes Rerum Balearium (nova etapa) (Mallorca) 1 (1990) 187-211.

175 Cf. el fragmento citado en «Nova documentació», pp. 193-194.

176 Reflexiones, p. 58.

177 Anne Thérèse de Marguenat de Courcelles (1647-1733) autora de escritos sobre pedagogía y sobre la familia.

178 Jeanne Marie Le Prince de Beaumont (1711-1780). Publicista y autora de obras pedagógicas.

179 Ibid.: pp. 59-60. Y añade: "para ninguna de ellas me atrevería á decir lo que el Anacreonte español D. Estevan de Villegas á su Drusila arguyente», y cita un largo pasaje de la cantilena 28.

${ }^{180} \mathrm{IV}$, dis. 11, p. 2, \$. 5, nota 1 del número 22.

181 Cf. SAlord Rupoll, Josefina: «Presències de l'espiritualitat il-lustrada a Menorca», en Revista de Menorca (Maó) (1991) p. 502, donde alude al conocimiento que tenía Roig del santo. 
todo, no siempre esto nos ha de llevar a apreciarla como trabajo propio, puesto que los sermonarios y el "Año Cristiano» de Croiset, a quien cita en la obra histórica que hemos comentado, dan semejantes contenidos. Con todo, en un sermón sobre S. Vicente de Paul destaca su promoción de la piedad y de la cultura del clero, con recursos que por entonces los obispos implantaban en Mallorca ${ }^{182}$. El mismo Roig fue comisionado por el obispo Rubio Benedicto a predicar ejercicios, tarea que por entonces era casi exclusiva de los presbíteros de la Congregación de la Misión, una vez que los jesuitas habían sido expulsados ${ }^{183}$.

Sin embargo, Roig refleja la anemia espiritual carácterística de su época, en la cual los místicos castellanos de los ss. XVI-XVII eran de difícil acceso, por falta de ediciones ${ }^{184}$. En un sermón predicado en el primer templo dedicado a santa. Teresa, el del convento de las carmelitas descalzas de Palma, no hemos logrado hallar un solo vestigio de que hubiera leído a la santa. Hay una mención a un dicho que el predicador le atribuye, pero que bien puede sacarse del refranero popular: «A quien se aníma, Dios le ayuda» ${ }^{185}$. Conocemos otro pasaje, en el cual recuerda como la santa, reaccionando ante las escisiones confesionales de la época, proclamaba "Yo soy hija de la Iglesia» ${ }^{186}$. Esta frase, transmitida con variantes, tampoco implica que Roig hubiera leído a la fundadora de Ávila. Santa Teresa era más invocada que leída por los ilustrados y liberales ${ }^{187}$.

Abierto a la crítica histórica y aunque manejara un vocabulario próximo al de los ilustrados, en manera alguna cede a lo que pueda atacar la fe. Tampoco está dispuesto a aceptar que se borren de la sociedad las manifestaciones públicas de la religión. Por esto, califica de «tiempos peligrosos» (cf. 2Tim 3,1) aquellos días, porque, aludiendo a la Revolución Francesa, «una chusma vil de libertinos conspirados contra el Señor [...] niega serle debido ningun culto ex-

182 Sermon de S. Vicente de Paul fundador de la Congregación de la Mision, y de las Hijas de la Caridad. Que en su iglesia de Palma, y en su fiesta predicó (...) (En la Imprenta Real) Mallorca M.DCC. XCVII. Hay 80 citas a pie de página, la mayoría bíblicas, pero una vez critica a Voltaire, en la n. 68 y otras cita bibliografía contemporánea. Cf. p. 24, sobre los Ejercicios Espirituales a todo el pueblo; p. 27, a causa de la dependencia de los presbíteros de la Misión respecto de los obispos, en sus ministerios, p. 28, sobre el estudio de la teología moral.

183 Cf. algunas referencias en $M n$. Antoni Roig, p. 40, con la nota 20.

184 MeSTRE SANCHIS: «Religión y cultura en el siglo XVIII español», pp. 666-667.

185 Ver el sermón, que citamos en la nota siguiente, p. 8. No hemos hallado una sola cita tomada de una obra de la santa de Ávila, a pesar de lo que decimos en la mencionada nota. Cf. LAMARCA LANGA: La cultura del libro, pp. 60-61, donde apunta una mayor presencia de la santa en las bibliotecas valencianas, sin que, por otra parte, podamos saber si se trataba de ediciones recientes o antiguas.

186 Oración que en la Solemne fiesta celebrada en la Iglesia del Convento de Religiosas de la Purísima Concepción de Mabon, p. 31. Otra versión de la frase sería "Quiero morir hija de la Iglesia». En la $V i d a, 33,5$ y en el epílogo de las Moradas hay expresiones que pudieron originar las máximas atribuidas a la reformadora del Carmelo.

187 APPOLIS: Les jansenistes espagnols, p. 164. Pueden verse los intereses que se escondían bajo esta invocación.

Hispania, LXII/3, núm. 212 (2002) 907-956 
terno» ${ }^{188}$. No sólo esto, sino que tacha de conciliábulo al sínodo de Pistoia, y lo compara al llamado Latrocinio de Éfeso. Lo menciona, porque criticó la veneración de las imágenes, y aquí Roig quiere defender el culto a la Virgen María ${ }^{189}$. $\mathrm{Si}$ antes habló de tiempos peligrosos, aludiendo a Pistoia califica a los días en que vive como "dias malos», que le hacen entrar en «una triste época» ${ }^{190}$. En Roig tenemos un caso plausible de aceptación de «las luces» y de nítida fidelidad no sólo a la fe, sino también a la doctrina católica. Batllori escribió que si tuviéramos que excluir de la Ilustración a las personas que no fueran radicalmente racionalistas, materialistas, o deístas, esta historia se reduciría a muy poca $\cos ^{191}$. Precisamente en la ausencia de espíritu anticristiano estriba una característica diferencial de la Ilustración española ${ }^{192}$.

Roig sintió la urgencia de reafirmar la dignidad e identidad de su pueblo, que en menos de un siglo había conocido regímenes tan diversos como el de la monarquía de los Áustrias, experiencias de los Borbones, seguidas de largos años de dominación inglesa (1713-1756) posteriormente la ocuparon los franceses (1756-1763) y de nuevo los ingleses (1763-1782 y 1798-1802) con el interregno de dominio español, pero ya borbónico (1782-1798). Con todo, en la tierra de Roig había un pueblo de antigua raigambre, que mantenía su identidad, a pesar de que era dominado por poderes extraños. $Y$ hacia su reivindicación se encaminó, desde su parroquia mallorquina. Reaccionaba Roig ante el retroceso que significaba, desde su punto de vista de presbítero abierto a las nuevas corrientes, la nueva vinculación del catolicismo con el poder borbónico, después de la conquista de 1782. No magnifica la época de dominación británica; pero había transcurrido sin la Inquisición y sin las conocidas intervenciones para-episcopales de los reyes del s. XVIII, de marcada tendencia regalista $^{193}$. El recién llegado a Menorca, el teniente vicario del ejército, Dionisio Muñoz Nadales, aspirante a ser el primero de la nueva serie de obispos que se vislumbraba como próxima, tendía a colocar las estructuras eclesiásticas al ser-

188 Sermón que con motivo de la traslación del Santísimo Sacramento y de la Imagen de N. Sra. del Carmen a la nueva iglesia de los carmelitas de Palma dixo (...). Dia 5 de julio del Año de 1802. Palma de Mallorca. En la Imprenta de Tomas Amorós. Impresor del Santo Oficio [1802]. Las 21 páginas en $4^{\circ}$, de letra pequeña, van seguidas de 144 referencias. El pasaje al que nos referimos, se halla en la p. 11; cf. hacia la conclusión del sermón, pp. 20-21.

189 Ibid.: p. 12.

190 Ibid.: pp. 13 y 12, respectivamente.

191 «Un problema central», p. 299.

192 VILANOVA, Evangelista: Història de la Teologia cristiana. Vol. III. Segles XVIII, XIX i XX, Barcelona, Col-lectània Sant Pacià, N ${ }^{\circ} .41$ - Facultat de Teologia de Catalunya. Editorial Herder, 1989, p. 187.

193 Cf. SAlord I RIPOLl, Josefina: «Presències de l'espiritualitat il-lustrada a Menorca», Revista de Menorca (Maó) (1991) 506; Id.: «Església i menorquinitat cultural: el traçat d'un itinerari», en Publicacions des Born. Ciutadella de Menorca, Cercle Artístic. Treball de la Secció d'Estudis, núm 1 (Número extraordinari amb motiu del bicentenari de la Restauració de la Diòcesi de Menorca, amb la col-laboració del Bisbat de Menorca) 1997, p. 99. 
vicio de la monarquía, después de años, durante los cuales se había hecho necesario y hasta fácil marcar distancias respecto de la monarquía británica, anglicana de confesión ${ }^{194}$. Puede ser que las insistencias políticas que le llegaban le condujeran a buscar un nuevo ambiente. De hecho, parece, que su decisión de presentarse a oposiciones a cura párroco en Mallorca responde al cansancio que llegó a padecer como Vicario General, a causa de sus relaciones institucionales, más que pastorales.

Concluimos este apartado, mencionando otros cultivadores de la historia. En efecto, la renovación intelectual que se producía en el convento de los capuchinos, a la cual hemos aludido al hablar de Cladera, promovió un giro en la trayectoria de los historiadores. Fray Lluís de Vilafranca (1770-1847) ${ }^{195}$, y el presbítero Josep Barberí (1766-1826) ${ }^{196}$, fueron juzgados por Jaime de Villanueva hombres de «buena crítica», de quienes alaba el método de trabajo ${ }^{197}$. Los compara con los antiguos historiadores mallorquines y con el francés $M$. De Hermilly, de quien resalta los muchos errores, y añade que fácilmente se percibirá de lo poco temible que es este leon ${ }^{198}$. Ambos eclesiásticos fueron amigos y colaboradores de Jovellanos, durante sus años de prisión en el castillo de Bellver ${ }^{199}$. Queda por investigar hasta qué grado de compenetración llegaron con el prisionero. Indudablemente, eran capaces de entenderse con un manifiesto ilustrado. El catálogo de la biblioteca de Barberí contiene muchas obras de los clásicos latinos, algunos castellanos y bastantes volúmenes en francés, si bien los títulos parecen que se inclinaba hacia la apologética ${ }^{200}$.

${ }_{194}$ Cf. SALORD I RIPOLL, Josefina: Ferreries dins el paisatge il-lustrat d'Antoni Roig, en Batec de pedres centenàries. Recull de conferències pronunciades a la parròquia de Sant Bartomeu amb motiu de la celebració del 200 aniversari de l'acabament de les obres de l'església. Parròquia St. Bartomeu - Ajuntament de Ferreries 1998, p. 71.

195 Cf. sobre el interés del P. Vilafranca y los demás capuchinos por la arqueología, cf. DE Montaner Alonso, Pedro, «El desaparecido gabinete de Antigüedades de los Capuchinos de Mallorca y el origen de la Colección Vivot», en Mayurqa, (Mallorca) nº 15 (1976) 199-208.

196 BOVER: I, $n^{\circ} .90$, pp. 63-64.

197 VIllanUEVA, Jaime: Viage Literario à las Iglesias de España: XXI: Viage à Mallorca, I, Madrid 1851, p. 29.

198 Ibid.

199 GUASP POU, Felipe: «El Dr. D. José Barberi» (Continuación) III, en BSAL (Mallorca) 21 (1926-1927) 87-89. En Origens del Cristianisme a les Balears, I, p. 37, recogemos cómo duda del viaje de S. Pablo a las Baleares, aún cuando lo afirmaban otros autores; en p. 286, vemos cómo rechaza la conquista de las islas por los godos, etc.

200 GUASP POU: «El Dr. D. José Barberi» (Continuación) en BSAL (Mallorca) 21 (1926-1927) «Apéndice de documentos», XVI, 152-155.

Hispania, LXII/3, núm. 212 (2002) 907-956 


\section{OTRAS MANIFESTACIONES DE LA PREILUSTRACIÓN}

\section{Un pueblo y un clero moderados}

Hay unas frases de Miquel dels Sants Oliver a las cuales hemos de prestar atención. Se hace eco de los edictos episcopales, emanados durante el s. XVIII, en los cuales se critican las malas costumbres, violaciones de clausura, raptos, asesinatos. Alguna vez los protagonistas son eclesiásticos. Oliver llega a hablar de la plaga de los abates á la francesa, mujeriegos y afiligranados ${ }^{201}$.

Uno desearía disponer de estudios más analíticos, para dar más amplitud a nuestras informaciones. De todas formas, puede ser un buen indicio comprobar que en una comparación que fácilmente se puede establecer entre el s. XVII y el s. XVIII, a partir de los datos que recogió Álvaro Campaner en su Cronicón Mayoricense, fácilmente vemos que el segundo sale favorecido en cuanto a la disminución de los casos de muerte violenta. No debilita el careo el hecho de que contemporáneamente el compilador ofrezca datos para que observemos un alza en número de presbíteros asesinados ${ }^{202}$. Si atendemos a otra fuente, que son los documentos episcopales, incluidas las actas de las visitas pastorales y los informes enviados a Roma con ocasión de las visitas ad limina ${ }^{203}$, observaremos que muestran que hay un clero más preparado y asiduo en los ejercicios ascéticos, en la plegaria y en unas prácticas que buscaban una capacitación para la resolución de casos de moral, tarea muy acorde con la preocupación por la ética y un cierto rigor. Sin que pretendamos corregir a Oliver, queremos apuntar que posiblemente su imagen del s. XVIII estaba viciada por un conservadurismo historiográfico no siempre atento a los datos, y muy pendiente de la imagen que proyectaba una idea de España, y en este caso de Mallorca, polarizada en los Reyes Católicos, los Áustrias y los clásicos castellanos. La modernización económica, con avances en una convivencia menos violenta, no contaba.

Durante este siglo, la renovación espiritual del clero dependió en grado superior de la aplicación metódica de prácticas de piedad, más que de una configuración de una nueva forma de espiritualidad que, por ejemplo, hubiera tenido cuenta, por un lado, la crítica al exteriorismo de las formas barrocas y, sobre todo, hubiera supuesto una vuelta más clara a la Biblia, como se iba pidiendo

201 OLIVER: Mallorca durante la primera revolución, p. 14.

202 Campaner y Fuertes, Álvaro: Cronicón Mayoricense, Noticias y relaciones históricas de Mallorca desde 1229 á 1800 . Segunda edición aumentada con el Repertorio alfabético de todas las noticias que contiene el «Cronicón Mayoricense» y una noticia acerca del «Cronicón» y su autor, por Luis RIPOLL, Palma de Mallorca, 1967. Rullan, José: Historia de Sóller en sus relaciones con la general de Mallorca, I, (Imprenta de Felipe Guasp y Vicens) Palma 1875, p. 601, ofrece unas estadísticas comparativas, que muestran que en el $s$. XVIII se produjo una reducción de los asesinatos en la proporción de 43 a 8 .

${ }^{203}$ Hay que observar que las relaciones de estas visitas son notablemente escasas en la segunda mitad del s. XVIII. 
desde el campo de los preilustrados. La misma vuelta a la disciplina antigua, con un mayor conocimiento de las fuentes patrísticas, pudiera haber originado un estilo de ministerio desligado del sistema beneficial. Al menos, parece, que lo hubiera sujetado a una crítica.

Con todo, las grandes líneas de la vuelta a las fuentes no llegaron a tomar fuerza en los seminarios. Tampoco la patrística ni la investigación bíblica entran en nuestra Universidad. Por esto, básicamente, la mayor parte del clero, con educación postridentina y con piedad barroca y después romántica, se sorprendió con la Ilustración y el sistema liberal que se implantó en el s. XIX.

Añadamos, a este respecto, una palabra de hermenéutica. Los edictos episcopales, en tiempos pretéritos, adoptaban un género literario conminatorio y crítico. Se asemejaban a los sermones morales de las misiones populares. Así cómo nadie se atreverá a describir una época con los solos sermones de los misioneros, tampoco, para ello, basta apelar a los edictos utilizados por Oliver. Los ficheros de la Guardia Civil son imprescindibles para la historia de un pueblo; pero no pasan de ser una fuente más, a integrar con aguas más limpias de otros manantiales.

De lo dicho se infiere que la reforma tridentina y las corrientes más humanas que penetraban en el s. XIX limaron aristas de la vida. Otra parte vino del lento crecimiento económico, aspecto más estudiado por los historiadores.

\section{Un nuevo estilo de Vida Religiosa: la felicidad del pueblo}

Ya en la primera mitad del s. XVIII, la vida religiosa femenina hace intentos de saltar de la clausura monástica, para iniciar una forma más abierta, buscando objetivos apostólicos. A las Terciàries Franciscanes de Sa Bassa, de Manacor, las fundó el año 1740 Sor Rosa Maria Parera. Además de profesar los tres votos religiosos, se regían por unos estatutos y se dedicaban a la educación de las niñas, y, en especial enseñaban la Doctrina cristiana y las labores entonces características de la mujer ${ }^{204}$.

Aunque este grupo constituyera una fundación innovadora, todavía no se detectan en él las influencias ideológicas de la preilustración, a diferencia de lo que sucede con Mn. Antoni Roig i Rexach ${ }^{205}$, de quien ya hemos hablado, desde otras perspectivas.

Roig había sido párroco y Vicario General en Menorca, cuya iglesia estaba integrada en el obispado de Mallorca. De su isla nativa Roig pasó a Mallorca. Aquí fue párroco de uno de los núcleos de población más importantes, Felanitx. Ante las carencias que observó, con algunas mujeres dio comienzo a una

${ }^{204}$ Cf. TRUYOLS, Antonio: Sor Rosa $M^{a}$. Parera y las Hermanas Terciarias de S. Francisco de Manacor, Palma, [Artículos publicados en El Heraldo de Cristo] 1922. Véase la p. 9.

${ }^{205}$ A propósito de esta precocidad mallorquina, en cuanto a crear comunidades «útiles», en comparación con Cataluña, cf. RENOM I FERRER: Miquel Ferrer i Bauçà, p. 42.

Hispania, LXII/3, núm. 212 (2002) 907-956 
Casa de Caridad. Es el inicio de una línea de vida religiosa apostólica, que se encuadra dentro de la nueva mentalidad de la época, que valora las instituciones de la Iglesia a partir de su utilidad y teniendo en cuenta los servicios sociales que presta. Los valores transcendentes no entran en el horizonte de quienes gobiernan. Es obvio; pero no lo es tanto que tuvieran razones sólidas para que se consideraran con poderes legítimos para controlar a quienes se organizaban con aquella perspectiva.

Mn. Roig supo expresarse con el lenguaje de los ilustrados, cuando explicó a la SEMAP que su objetivo no era otro que el de «hacer más felices a mis feligreses» ${ }^{206}$. No en vano él era un de los presbíteros de la Part Forana que se había inscrito como miembro de la SEMAP. Desde la Sociedad se le comunica que consideran su fundación como provechosa para el bien público ${ }^{207}$, según hizo constar su secretario, Josep de Togores i Sanglada. Desde esta entidad siguieron de cerca la fundación, alentaron a sus promotores para que descubrieran la verdadera caridad ${ }^{208}$.

Algo que, una vez más, conviene revisar es lo que otros historiadores escribieron, acerca del posible calco practicado por Mn. Roig, sobre la obra de S. Vicente de Paúl ${ }^{209}$. Si en nuestro citado ensayo biográfico quedó patente que era difícil probar que conociera con cierto detalle a la institución de las Hijas de la Caridad, ahora, que hemos de descartar una estancia larga en Aviñón del fundador de la Casa de Caridad de Felanitx, creemos que el influjo vicenciano en esta obra, al menos en su inspiración y en sus orígenes, es tenue. Habrá que conectar más el sentido cristiano de Roig, vivido fervientemente, con su mentalidad de preilustrado, para poder encontrar la fuente de inspiración que le llevo a la fundación de la Casa de Caridad de Felanitx, en 1798.

Con estos datos, percibimos la existencia de la semilla de la floración exuberante de institutos de vida apostólica, que llenará el s. XIX.

\section{Tentativos para una renovación pedagógica}

El obispo Nadal había ideado aplicar las doctrinas pedagógicas de Pestalozzi, sirviéndose de los franciscanos de la primera orden, no obstante, la aplicación tuvo lugar en la realización de un proyecto llevado a cabo con la aprobación del

\footnotetext{
${ }^{206}$ Alguna otra expresión, en este sèntido, queda recogida en AMENGUAL i BatlE: Antoni Roig $i$ Rexart, p. 36, nota 19.

${ }^{207}$ Cf. PASCUAL, Nicolás: Don Antonio Roig y su fundación de Hermanas de la Caridad de San Vicente de Paúl. Institución mallorquina del s. XVIII, Palma de Mallorca 1960, pp. 189-191. AMENGUAL I BATLE: Antoni Roig i Rexart, pp. 22-23.

208 Véase Amengual i Batle: Antoni Roig $i$ Rexart, pp. 22-23. Sobre Togores, cf. MaS I VIVeS, Joan: Josep de Togores $i$ Sanglada comte d'Aiamans (1767-1831). Biografia d'un il.lustrat liberal, Abadia de Montserrat, Departament de Filologia catalana i lingüística general. Universitat de les Illes Balears) (Biblioteca Miquel dels Sants Oliver, 1),1994.

209 PASCUAL: Don Antonio Roig, p. 108.
} 
Ayuntamiento de Sóller, en 1802, aún antes de que F. Woitel lo ensayara en Tarragona $^{210}$ y de que visitara Mallorca, el año 1816, fecha en la cual el proyecto de Nadal fue configurándose, contando con el presbítero Nicolau Pons. ${ }^{211}$ Con la SEMAP contribuyó en el mantenimiento de la Escuela de Bellas Artes y al fomento de los estudios de náutica. Fomentó Nadal estudios para combatir la pobreza, con alternativas a partir de trabajos sociales, al tiempo que premiaba propuestas para proyectos industriales convenientes a la Isla. Fue el iniciador del Col.legi de la Puresa de Maria Santísima, cuya pervivencia se mantiene en la Congregación homónima, surgida posteriormente, que ha alcanzado una difusión intercontinental.

Hemos de mencionar a otra persona poco estudiada. Se trata del clérigo regular teatino, Fulgenci Palet. Era un temperamento de tendencias liberales y de estilo poco conventual. Con el obispo Nadal, además de este talante, compartió la inquietud por las innovaciones pedagógicas ${ }^{212}$. En 1807 fue enviado a Madrid como observador del Instituto Pestalozziano, obteniendo antes la recomendación de la SEMAP213.

\section{CONCLUSIÓN}

Al final de este recorrido, comprobamos que hemos podido realizar algunas catas, en un terreno poco explorado. Sin embargo, cabe reconocer que hemos avanzado relativamente poco sobre lo que, por ejemplo, ya recogió hace casi siglo y medio Bover, acerca de las relaciones que mantuvieron con los enciclo-

\footnotetext{
210 SuReda García, Bernat: «Reformisme il-lustrat i educació elemental a Mallorca (17751835)», en Sureda [GARCía], Bernat, Antoni J. Colom, Francesc J. Díaz, Jaume Oliver, Gabriel Janer Manila, L'educació a Mallorca (Aproximació Històrica) Mallorca, Els Treballs i els Dies, 16.Editorial Moll, 1977, pp. 30-31.

211 DURAN I PASTOR, Bernat Nadal, p. 41.

212 Prohens, Jaime: «Los Teatinos en Mallorca. Relación del personal de la casa de S. Cayetano de Palma de Mallorca», Regnum Dei. Analecta Ordinis Clericorum Regularium (Theatinorum) (Roma) 4 (1948) 161-162.

213 SuREdA GarCÍA: «Reformisme il-lustrat», p. 30. Más recientemente ha incidido en este punto, COMAS, Francisca: «Los teatinos y su influencia en la introducción de los primeros métodos de renovación pedagógica en Mallorca a principios del siglo XIX», Regnum Dei, (Roma) 124 (1998) 247-267, especialmente las pp. 251-258. Guillem Ignasi de Montis emite un juicio crítico sobre Palet, atacándolo de poco modesto, cf. la carta 23, en MOLL BLANES: «El liberalismo», p. 204; VENY BAllester: La Real Casa de San Cayetano, pp. 337-338, donde dice que Palet «Compartía, en amplia medida, la mentalidad liberal de estos Ilustrísimos personajes», es decir, la de Nadal y del visitador de los regulares, el cardenal Luis $\mathrm{M}^{\mathrm{a}}$. de Borbón. En la carta que escribía el P. Ildefons Bauçà, al Prepósito General de la Orden Teatina, le dice que el P. Palet «no desea sino libertad», Ibid. p. 338. Palet fue un adversario calificado del integrista P. Strauch, cf. pp. 353-380. La narración de muchos hechos sigue a OLIVER, La primera revolución, en clave integrista.
} 
pedistas Bonaventura Serra y otros ${ }^{214}$. Los investigadores más recientes no han aportado sensibles novedades con respecto a cuanto ya conocíamos mediante la búsqueda de Miquel dels Sants Oliver, Antoni Pons ${ }^{215}$ y Josep Sureda Blanes ${ }^{216}$.

$\mathrm{Si}$ atendemos a cuanto hemos insinuado, podemos observar que los rasgos de la preilustración en Mallorca muestran sus paralelos con los que se perciben en sus contemporáneos peninsulares y menorquines. En general, sus representantes salen de la endogamia y saben viajar o al menos mantener contactos con centros y personas innovadores de otros países. Este hecho no les lleva a renunciar a valores tales como el lulismo, que ya entonces tenía sus mejores representantes en Alemania.

Estos preilustrados hallaron cabida en los centros de enseñanza superior, todos bajo control eclesiástico. La renovación cohabitó con las tendencias más herméticas. Pero en manera alguna los amigos de los Ilustrados fueron excluidos de la Universidad ni tampoco se autoexcluyeron.

Pasando al campo de la pastoral, hemos de partir del hecho bien claro, cual es la pervivencia del modelo postridentino. Este reformismo, en su vertiente moral, pudo cohabitar con las tendencias éticas que propugnaban los reformadores regalistas. Una sobriedad de costumbres, un cierto cultivo del estudio, etc. tenían ya seculares antecedentes. Que con estos ingredientes no se fomentaba el entusiasmo espiritual ni la mística, también es obvio.

Añadamos que, junto a los catecismos postridrentinos, medievalizantes y muy conceptuales, se abrió paso el de Fleury, lo cual revela la capacidad de una cierta renovación, aunque fuera sólo en los medios escolares de Palma. Más allá, en la incorporación de la Biblia a la formación y celebración cristianas, no se llegó.

Por tanto, podemos asumir una comprobación que, en nuestros días se va extendiendo, y es que en Mallorca hubo un movimiento preilustrado, en el cual estuvieron implicadas muchas personas pertenecientes a las órdenes religiosas y al clero, entendido tanto en sentido estricto, es decir, incluyendo a los adscritos a él por la tonsura, como en el sentido más restrictivo, como hoy se acepta a primera vista, cuando se le identifica con el presbiterado. Hablamos de preilustración, porque no aparecen en estos intelectuales actitudes críticas, que les lleven a debilitar su fe y, sobre todo, no aplican a la Escritura los principios del racionalismo. Hasta los que podemos considerar como representantes más netos de la Ilustración, como Nadal y Cladera, se profesan decididamente católicos.

Exceptuando los dos últimos eclesiásticos que acabamos de mencionar, los preilustrados mallorquines pertenecientes al clero no presentan antecedentes

${ }^{214}$ PIÑA Homs: «Del Decreto de Nueva Planta», con el epígrafe «La revolución intelectual del siglo XVIII y su impacto sobre Mallorca», pp. 351-360, ya queda anticuado. También tienen más pretensiones MOLL BLANES, Isabel, y Jaume SUAU PUIG: Memoria explicativa del estado de la Isla de Mallorca en el siglo XVIII, a FERNÁNDEZ, Roberto, (ed.): España en el siglo XVIII. Homenaje a Pierre Vilar. Prólogo de Josep FonTANA, (Editorial Crítica) Barcelona, 1985, pp. 285-288.

215 PONS: Dietari del Dr. Fiol, pp. XXIX-LIV.

216 SUREDA BLANES: Petites històries, especialmente, pp. 24-48.

Hispania, LXII/3, núm. 212 (2002) 907-956 
que les constituyan en eslabones declarados que les vinculen al liberalismo, presente en Mallorca desde los inicios del s. XIX, como hemos observado en Guillem Ignasi de Montis. Omitimos a Joan Muntaner i García, Vicario General de Nadal y de sus sucesores, porque, aunque juzgamos que tuvo más influjo que el mismo Nadal, lo consideramos perteneciente al s. XIX. La apertura de aquellas personas se limitó al campo de la crítica histórica, filosófica y no se contagió expresamente con el bullir sociopolítico incipiente. Con todo, el substrato ideológico que les sustentó, al menos en algunos, integraba actitudes, métodos de trabajo y obras que eran un antecedente de unos nuevos estilos de vida.

Posiblemente la historiografía ha sido injusta con estos denodados trabajadores, atentos al ritmo histórico. Desde el estudio de la riqueza de las grandes crónicas medievales XIII-XIV y Ramon Llull, los historiadores tienden a saltar demasiado directamente hasta Josep $\mathbf{M}^{\mathrm{a}}$. Quadrado. El puente es avasalladoramente largo. No une riberas, sino que las ignora. Más aún, creemos que esta interpretación no se sostiene ni siquiera a priori. Constándonos que existían contactos con los ilustrados foráneos, y hasta con los enciclopedistas, es obligado intentar encontrar a los simpatizantes por lo nuevo, que necesariamente deben darse en estas situaciones. De ahí el temor del poder absoluto, fuera civil o eclesiástico. Y estas personas existían. Por esto, la artificialidad de tan dilatado intervalo posiblemente se deba, en parte, a la distorsión que provocan los dualismos interpretativos, con raíces en la reacción que sintieron muchos historiador ante la primera revolución de inicios del s. XIX. Aquella convulsión aparecía como un fenómeno ajeno al buen sentido tradicional, incrustado en Mallorca durante la centuria precedente. Por lo cual, el regreso hacia el s. XVIII no se consideraba fecundo; mas bien se dictaminaba que quizás era insano. En definitiva, se optó por olvidarlo.

Por otra parte, queda por calibrar la penetración real de las ideas de los preilustrados, y ver cómo, por ejemplo, los filoliberales, el obispo Nadal i Crespí, con su vicario general, Joan Muntaner i Garcia, y los liberales mallorquines del s. XIX, bebieron en estos cauces. La historiografía más conservadora ha tendido a tejer un velo de silencio sobre las tendencias renovadoras, que pululaban en la iglesia en Mallorca. Es cierto que nunca llegaron a ser mayoritarias. En 1821, con el traslado a Toledo del sucesor de Nadal, Pedro González Vallejo, la línea eclesiástica ideológicamente conservadora se impuso en la sede episcopal mallorquina hasta el postconcilio del Vaticano II. Desde este punto de vista, el pueblo de Mallorca no fue adecuadamente preparado para encajar con tolerancia y sentido de identidad cristiana los vaivenes del sistema liberal, en el siglo XIX. Las energías se canalizaron, sobre todo, hacia la dura reacción.

Es cierto que la prensa llamada «servil» tenía una clientela muy consolidada entre los medios eclesiásticos del primer cuarto del s. XIX ${ }^{217}$. Las represiones de que fueron objeto los liberales, por una parte, y el sectarismo de muchos

\footnotetext{
217 FERRER: «Aspectes de la difusió de la premsa política», pp. 46-47.
} 
de ellos por otra, cercenaron la paulatina penetración de la aceptación de los derechos humanos, hoy asumidos conciliarmente.

Cuanto hemos dicho, tiene su mayor aplicación a la ciudad de Palma. Por eso, será preciso explorar la incidencia de las nuevas ideas en las poblaciones foráneas, que sumaban dos tercios largos de la población total de Mallorca. Es importante esta indicación, porque, en general, en estos lugares el clero no producía materiales impresos, pero tampoco sus miembros pensaban en un sólo sentido. Es razonable lanzar la hipótesis según la cual los nobles inscritos en la SEMAP buscarían para los beneficios, que estaban bajo su patronato en sus haciendas foráneas, a clérigos adictos a sus ideas o, al menos, maleables. El proletariado clerical nunca ha tenido muchos motivos para estar con los que dominaban, fueran los caciques o fueran los eclesiásticos de superior rango.

Posiblemente el radicalismo antidemocrático del dominico Felip Puigcerver, en su obra contra el liberal Joaquín Lorenzo Villanueva, se deba más al ambiente enrarecido que se había creado, que a las razones científicas, cuando en nombre de santo Tomás de Aquino cierra todas las puertas a la soberanía del pueblo ${ }^{218}$. A este propósito, Marcelino Menéndez Pelayo tiene una expresión muy significativa, acerca de su visión de la tradición española, que le ha hecho maestro de muchos eclesiásticos historiadores, y algunos de ellos mallorquines. Después de hablar de Fr. Francisco Alvarado, el Filósofo Rancio, dice: «En él solo y en el P. Puigserver vive la tradición de nuestras antiguas escuelas» ${ }^{219}$.

Aunque esta mentalidad se impuso como dominante durante muchos años, no podemos menos de repetir una observación, que no por obvia deja de tener importancia, y es que este modo de ver representa no una continuidad sino una ruptura con una concepción propia de algunos grandes representantes de la escolástica moderna, especialmente la española, de los ss. XVI-XVII, según la cual el origen del poder se encuentra en el pueblo ${ }^{220}$. Evidentemente, la ruptura se dio con mucha anterioridad, cuando las doctrinas de los escolásticos modernos llegaron a la práctica, tanto en Castilla, con la rebelión de las Comunidades, como en América con Bartolomé de las Casas. La doctrina, con poca incidencia en las universidades hispánicas, pasó a las protestantes, que siguie-

${ }_{218}$ Véase el título bien significativo: El Teólogo democrático abogado en las angélicas fuentes, ó respuesta del Maestro Fray Felipe Puigserver de la orden de predicadores á la segunda parte del que se tituló Tomista en las córtes. En que se examina á fondo y se explica el sixtema de los antiguos teólogos sobre el orígen del poder civil, demostrando que la doctrina política de Santo Tomás destruye de raiz la pretendida soberania del pueblo y el derecho de establecer leyes fundamentales sin sancion, ni conocimiento del Príncipe. Mallorca, impr. De Felipe Guasp, impresor del Santo Oficio, $1815,4^{\circ}$., $100 \mathrm{pp}$. Villanueva había publicado Las angélicas fuentes ó el Tomista en las córtes. Cadiz, impr. de D. Diego García Campoy, 1813, $4^{\circ}$. Nótese la polarización, Mallorca reaccionaria, Cádiz liberal.

219 Historia de los Heterodoxos, II, pp. 737-738.

${ }^{220}$ CARR, Raymond: España 1808-1939, Esplugues de Llobregat, Ariel, 1970, p. 105, nota 36. Cf. Amengual i BAtLe, Josep: «Ensayo de un encuadramiento histórico de la fundación de la Congregación de Misioneros de los SS. Corazones", en Nuestra Regla de Vida. Comentario y estudios, Curia General MM. SS. CC., Madrid 1982, pp. 198-273. 
ron citando literalmente a Francisco de Vitoria y a Francisco Suárez. Pero, como ha escrito Joseph Pérez,

Literalmente, sí, pero la inspiración ya no era la misma. En el norte de Europa la ciencia política adquirió un carácter laico y se alejó de su base teológica. La soberanía ya no se fundamentaba en Dios, sino en el acuerdo de las voluntades humanas. El derecho natural que triunfó en el siglo XVIII olvidó sus lejanas raíces escolásticas y españolas. El pacto se convirtió en contrato social. El mundo había cambiado221.

Posiblemente la forma con la que se expresaban determinados liberales, a inicios del siglo XIX, y los sistemas con los cuales se aplicaba aquella concepción, causaron sorpresa. De todas maneras, es bien posible que las represiones de la década ominosa de Fernando VII sean el substrato más sólido de aquella mentalidad opuesta a las transformaciones, a la cual las revoluciones por una parte y los regímenes dictatoriales por otra han contribuido a darle pervivencia hasta el último cuarto del s. XX.

${ }^{221}$ Pérez, Joseph: Historia de España, Barcelona, Crítica. Grijalbo Mondadori, 1999, p. 245.

Hispania, LXII/3, núm. 212 (2002) 907-956 